\title{
Regulatory dendritic cells for immunotherapy in immunologic diseases
}

\section{John R. Gordon*, Yanna Ma, Laura Churchman, Sara A. Gordon and Wojciech Dawicki}

Department of Medicine, University of Saskatchewan, Saskatoon, SK, Canada

\section{Edited by:}

Lisa Helene Butterfield, University of Pittsburgh, USA

\section{Reviewed by:}

Theresa L. Whiteside, University of Pittsburgh, USA

Nick Giannoukakis, University of Pittsburgh, USA

*Correspondence:

John R. Gordon, Department of

Medicine, University of

Saskatchewan, Room 2D30.8, 107

Wiggins Road, Saskatoon, SK S7N

5E5, Canada

e-mail: john.gordon@usask.ca
We recognize well the abilities of dendritic cells to activate effector $T$ cell (Teff cell) responses to an array of antigens and think of these cells in this context as pre-eminent antigen-presenting cells, but dendritic cells are also critical to the induction of immunologic tolerance. Herein, we review our knowledge on the different kinds of tolerogenic or regulatory dendritic cells that are present or can be induced in experimental settings and humans, how they operate, and the diseases in which they are effective, from allergic to autoimmune diseases and transplant tolerance. The primary conclusions that arise from these cumulative studies clearly indicate that the agent(s) used to induce the tolerogenic phenotype and the status of the dendritic cell at the time of induction influence not only the phenotype of the dendritic cell, but also that of the regulatory T cell responses that they in turn mobilize. For example, while many, if not most, types of induced regulatory dendritic cells lead $\mathrm{CD}_{4}^{+}$naïve or Teff cells to adopt a CD25 ${ }^{+} \mathrm{Foxp}^{+}$Treg phenotype, exposure of Langerhans cells or dermal dendritic cells to vitamin $D$ leads in one case to the downstream induction of $\mathrm{CD}_{2} 5^{+} \mathrm{Foxp}^{+}$regulatory T cell responses, while in the other to Foxp3- type 1 regulatory $T$ cells $(\operatorname{Tr} 1)$ responses. Similarly, exposure of human immature versus semimature dendritic cells to IL-10 leads to distinct regulatory T cell outcomes. Thus, it should be possible to shape our dendritic cell immunotherapy approaches for selective induction of different types of $T$ cell tolerance or to simultaneously induce multiple types of regulatory $T$ cell responses. This may prove to be an important option as we target diseases in different anatomic compartments or with divergent pathologies in the clinic. Finally, we provide an overview of the use and potential use of these cells clinically, highlighting their potential as tools in an array of settings.

Keywords: dendritic cell, tolerance, regulatory T cell, immunoregulation, IL-10, retinoic acid, TGF $\beta$, vitamin D
During the 1960s, it was thought that macrophages, with their capacity to phagocytose antigens, were required to initiate immunity to foreign substances (1). It was known that lymphocytes were mediators of immunity, but we knew little about how antigens from an invading pathogen would reach the lymph node-sequestered naïve lymphocytes (2). There was a gap in the understanding of the initiation of adaptive immunity, a gap that Ralph Steinman and Zanvil Cohn set out to fill. When Steinman began to study the spleen and lymph nodes, he observed new cells that were distinct from macrophages in appearance and function. These dendritic cells, so named because of their

Abbreviations: AHR, airway hyperresponsiveness; APCs, antigen-presenting cells; BAL, bronchoalveolar lavage; BDCA, blood dendritic cell antigen; CTLA4, cytotoxic T lymphocyte antigen-4; DC10 or DC-10, semi-mature or immature, respectively, IL-10-differentiated dendritic cells; DC-SIGN, dendritic cell-specific intracellular adhesion molecule 3-grabbing non-integrin; Foxp3, the transcription factor forkhead box P3; ICOS and ICOS-L, inducible costimulator and inducible costimulator ligand, respectively; IDO, indoleamine-2,3-dioxygenase; ILT, immunoglobulin-like transcript; iTreg, induced $\mathrm{CD} 25^{+}$Foxp $3^{+}$regulatory T cells; $\mathrm{MHC}$, major histocompatibility complex; nTreg, naturally-occurring $\mathrm{CD} 25^{+} \mathrm{Foxp}^{+}$regulatory $\mathrm{T}$ cells; OVA, ovalbumin; RALDH2, retinaldehyde dehydrogenase 2; Teff cell, effector T cell; TLR, toll-like receptor; Treg cell, regulatory T cell. dendrite-like projections, had few lysosomes and only moderate phagocytic activity $(3,4)$, but they expressed high levels of major histocompatibility complex (MHC) molecules required for presentation of extra-cellular antigens (5). He also observed that dendritic cells were highly potent immune stimulators (6), and now we often speak of dendritic cells as the most proficient of professional antigen-presenting cells (APCs). By 1991, we had accumulated substantial knowledge on the role of the dendritic cell in the induction of immunity, but we were just beginning to recognize that extrathymic dendritic cells could also play central roles in the induction of tolerance (7), and it was not long before we began to understand more about tolerogenic dendritic cells and their potential applications $(8-10)$. We now appreciate that there are numerous discreet populations of naturally occurring regulatory dendritic cells, but focusing on understanding the immunobiology of these cells within their individual niches has given us substantial insights on how we can generate and employ regulatory dendritic cells for immunotherapeutic applications. While dendritic cells can activate either $\mathrm{CD} 4^{+}$or $\mathrm{CD} 8^{+}$, or even $\mathrm{CD}^{-} \mathrm{CD}^{-} \mathrm{T}, \mathrm{B}$, and NK cells to become regulatory cells, this review will be confined to a discussion on tolerogenic DC in the context of $\mathrm{CD} 4^{+} \mathrm{T}$ cells and their responses. We will first describe 
the populations of dendritic cells found in vivo and then look at the major populations of regulatory dendritic cells that have been induced exvivo, as well as the effector molecules employed by these cells.

\section{OVERVIEW OF DENDRITIC CELL BIOLOGY}

In general, dendritic cells express MHCII but lack T cell (CD3), B cell (CD19), and NK cell (CD56) lineage markers (11); some subsets of dendritic cells express the monocyte/macrophage (CD14) or NK cell/neutrophil and monocyte/macrophage (CD16) lineage markers, and others the CD4 and/or CD8 T cell subset markers. Dendritic cells are formed from bone marrow progenitors that in general give rise to circulating dendritic cell precursors $(12,13)$ that seed the peripheral tissues as immature cells (14). As quiescent or immature cells, they express receptors for, and have an innate capacity to respond to an array of inflammatory signals, including ligands for toll-like receptor (TLR), NOD-like receptors, and scavenger receptors, as well as inflammatory mediators, cytokines, and chemokines. The various sub-populations of dendritic cells can respond in a qualitatively and quantitatively distinct fashion to such environmental triggers and differentiate extensively to become immunocompetent accessory cells, such that they provide a crucial link between the innate and adaptive immune responses (15). They upregulate cell-surface expression of their antigen-presentation machinery, including processed antigen peptide-loaded MHCII (16) and co-stimulatory molecules as well as receptors for lymph nodehoming chemokines (e.g., CCR7), and they downregulate their phagocytic activities and receptors for local inflammatory signals (e.g., CCR5, CCR6) (14, 17). As dendritic cells mature, they lose their ability to process new peptides $(18,19)$ and migrate to their tissue-draining lymphoid organ, where they present their processed antigens to $\mathrm{T}$ cells in the context of cell-surface MHC (APC signal 1) together with supporting costimulatory molecules (e.g., CD40, CD86; APC signal 2) and T cell-polarizing cytokine signals such as IL-12 (20) (APC signal 3), inducing the $\mathrm{T}$ cells to differentiate into antigen-specific effector T cells (Teffs; e.g., Th1, Th2, or Th17 cells) (13). But dendritic cells can also provide a fourth APC signal of sorts to $\mathrm{T}$ cells, by which they direct the trafficking of the educated $\mathrm{T}$ cell. In the gut, retinoic acid and transforming growth factor (TGF)- $\beta$ produced by dendritic cells together induce $\mathrm{T}$ cells to express the $\alpha 4 \beta 7$ and CCR9 gut-homing receptors (21), while in the skin-draining lymph nodes vitamin $\mathrm{D}$ metabolites released by the dendritic cell induce $\mathrm{T}$ cells to express CCR10, such that they become responsive to the skin-homing chemokine CCL27 (22).

Tissue-resident dendritic cells that acquire innocuous environmental or self antigens in the absence of local inflammatory responses similarly migrate to the draining lymph nodes but, as more quiescent cells, overall they express lower levels of MHCII, co-stimulatory molecules, and IL-12, and secrete instructional regulatory mediators such as IL-10 or retinoic acid $(23,24)$. In this way dendritic cells that are presenting innocuous environmental antigens activate one of several types of regulatory T cell (e.g., Treg, $\operatorname{Tr} 1$, or Th3) responses that are associated with immune tolerance (Figure 1).

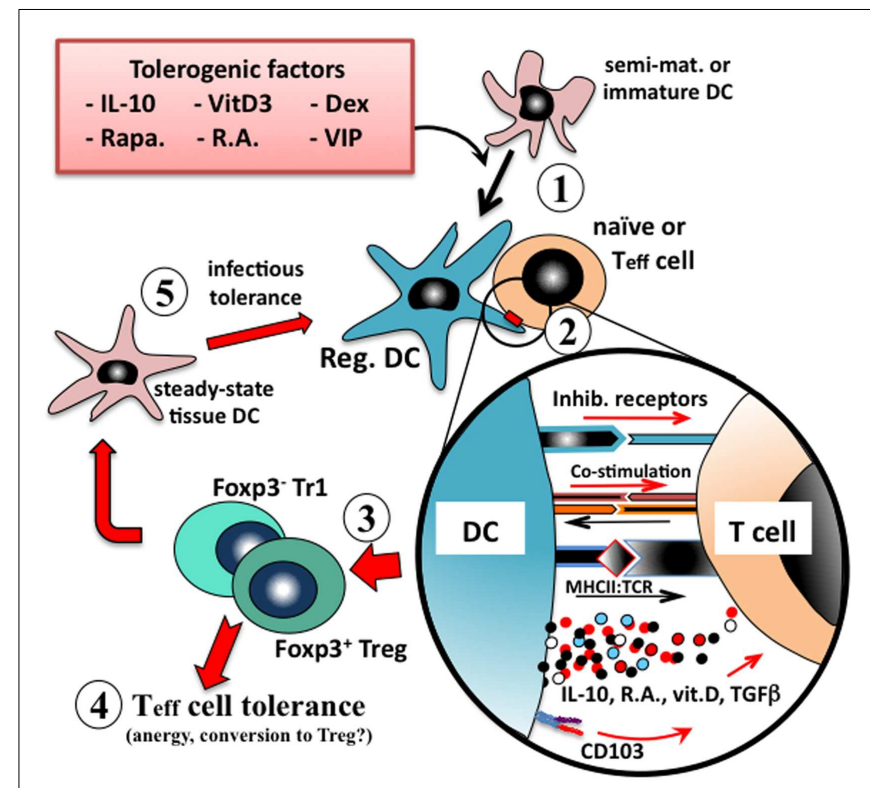

FIGURE 1 | Induction of immunologic tolerance by regulatory dendritic cells. Immature or semi-mature dendritic cells that are incubated with, or differentiated in the presence of, tolerogenic factors (e.g., IL-10, vitamin D3, corticosteroids, or retinoic acid) (1) adopt a regulatory phenotype. When these converted regulatory dendritic cells are pulsed with antigen and exposed to cognate naïve or effector T (Teff) cells (2), they present their processed antigen peptides in the context of $\mathrm{MHCll}$, and also lower levels of co-stimulation (e.g., CD40, CD86) to the T cells, but at the same time many types of tolerogenic cells also provide inhibitory receptor (e.g., ILT2, ILT4) signaling to the T cell. Counter-signaling from the engaged $T$ cell activates dendritic cell production of polarizing mediators (e.g., IL-10, TGF $\beta$ ), which together instruct the $T$ cell to adopt a regulatory phenotype. The nature of the instructional signals from the dendritic cell to the T cell determine whether it adopts an IL-10-secreting CD25+Foxp3 ${ }^{+}$Treg phenotype or an IL-10/TGF $\beta$-secreting Foxp3- ${ }^{-}$Tr 1 phenotype (3). These regulatory $T$ cells are able to suppress the responses of cognate or by-stander naïve or effector T cells in their microenvironment (4) and also to convert endogenous tissue dendritic cells to adopt a regulatory phenotype through induction of infectious tolerance (5), and thereby reinforce the tolerance phenotype.

\section{NATURALLY OCCURRING POPULATIONS OF DENDRITIC CELLS}

A large number of reports have described an array of dendritic cell types and subtypes in different organ systems and animals, and it is almost undoubtedly true that more will be described as we explore further. Many of these sub-populations are or can be tolerogenic as they are found in their steady state (e.g., pulmonary plasmacytoid or myeloid dendritic cells), but for most if not all of these there are inflammatory signals that can override this tolerogenic phenotype, converting these cells to an immunostimulatory phenotype. In some tissues (e.g., gut, liver) dominantly tolerogenic signals are constitutively expressed at high levels, while in other sites that are not routinely exposed to the external environment these signals may be much more subtle.

\section{DENDRITIC CELLS IN THE BLOOD}

Several distinct types of dendritic cells can be identified in human peripheral blood. There are two sub-populations 


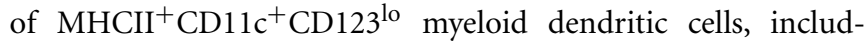
ing $\mathrm{CD} 1 \mathrm{c} /$ blood dendritic cell antigen (BDCA) $-1^{+}$cells and CD141/BDCA- $3^{+}$cells, as well as $\mathrm{MHCII}^{+} \mathrm{CD} 1 \mathrm{c}^{-} \mathrm{CD} 123^{\text {hi }}$ plasmacytoid dendritic cells that also express BDCA-2/CD303, BDCA4/CD304,IL-3RA, and ILT7 $(11,25)$. The CD141 ${ }^{+} \mathrm{MHCII}^{+} \mathrm{CD} 11 \mathrm{c}^{+}$ myeloid dendritic cell is the human counterpart of the murine $\mathrm{CD} 8 \alpha^{+}$dendritic cell (25). In the mouse, the identities of circulating tissue dendritic cell precursor(s) have not been all that well documented (26). We know that murine splenic and lymph node dendritic cells are continuously replaced from a pool of bloodborne precursors (27), that splenic $\mathrm{CD} 8 \alpha^{+}$dendritic cells most likely gain access to this organ via the vasculature (28), and that MHCII ${ }^{\mathrm{lo}} \mathrm{CD} 11 \mathrm{c}^{\text {lo }} \mathrm{pDC}$ do accumulate in the blood of mice (13, 28). While immunostimulatory (29) and tolerogenic (30) dendritic cells can be readily differentiated ex vivo from peripheral blood monocytes in humans, it was only recently that LPS stimulation of murine monocytes was reported to induce dendritic cell differentiation (31). These murine monocyte-derived dendritic cells express CCR7 and dendritic cell-specific intracellular adhesion molecule 3-grabbing non-integrin (DC-SIGN) and localize to $\mathrm{T}$ cell areas of lymph nodes, where they are highly effective in presenting and cross-presenting antigens (31).

In humans, the BDCA- $1^{+}$and $-3^{+}$myeloid dendritic cell populations can be mobilized from the bone marrow with Flt3 ligand alone while optimal plasmacytoid dendritic cells mobilization reportedly calls for use of Flt3 ligand and G-CSF (25). The circulating $\mathrm{BDCA}-1^{+} / \mathrm{CD} 1 \mathrm{c}^{+}$myeloid dendritic cell can secrete abundant IL-12 and prime cytotoxic $\mathrm{T}$ cell responses (32), while BDCA $-3^{+}$myeloid dendritic cells and BDCA- $2^{+}$plasmacytoid dendritic cells instead secrete IFN $\gamma$ and IFN $\alpha$, respectively, on activation (32). A minor population of tolerogenic IL-10-expressing $\mathrm{CD} 1 \mathrm{c}^{-} \mathrm{CD} 303^{-} \mathrm{CD} 14^{+}$dendritic cells has recently been described in human peripheral blood, although much of the data regarding their tolerogenic activities has come from studies with an in vitro analog of the circulating cell (33).

\section{INTESTINAL DENDRITIC CELLS}

The intestinal immune system routinely faces the challenge of discriminating pathogens from harmless commensal organisms and other (e.g., food) antigens, as a prelude to triggering effector and regulatory $\mathrm{T}$ cell responses, respectively (34). The gut-associated dendritic cells include those in the mesenteric lymph nodes (MLNs), intestinal lamina propria, and the isolated lymphoid follicles $(35,36)$. The lamina propria contains two populations of $\mathrm{CD}_{11 \mathrm{c}^{+}}$mononuclear cells, including $\mathrm{CD} 11 \mathrm{c}^{\mathrm{hi}} \mathrm{CD} 103^{+} \mathrm{CD} 11 \mathrm{~b}^{+} \mathrm{CX}_{3} \mathrm{CR} 1^{-}$cells and $\mathrm{CD} 11 \mathrm{c}^{\text {int }} \mathrm{CD} 103^{-} \mathrm{CD} 11 \mathrm{~b}^{+} \mathrm{CX}_{3} \mathrm{CR} 1^{+}$cells; the $\mathrm{CD}_{103}{ }^{+}$cells are bona fide dendritic cells while the latter $\mathrm{CD}_{103^{-}}$cells are now thought to be resident tissue macrophages (37). Under steadystate conditions, the $\mathrm{CD}_{103}{ }^{+}$dendritic cells express retinaldehyde dehydrogenase 2 (RALDH2) $(23,38)$, TGF- $\beta$ (39), and indoleamine-2,3-dioxygenase (IDO) (40), such that targeting of antigens to these cells leads to tolerance outcomes, while gut inflammation dampens TGF $\beta$ and RALDH2 expression in these cells, such that they instead induce vigorous $\mathrm{T}$ and $\mathrm{B}$ cell responses $(41,42)$. CD103, the $\alpha$ chain of the E-cadherin ligand $\alpha \mathrm{E} \beta 7$ integrin (43), is expressed on almost all lamina propria dendritic cells and a subset of MLN dendritic cells (44). It has been reported that gut luminal bacteria recruit lamina propria $\mathrm{CD} 103^{+}$dendritic cells into the gut epithelium, from which they extend filipodia into the lumen to sample gut antigens (37). RALDH2 is an enzyme that catalyzes the synthesis of retinoic acid, a vitamin A derivative, which plays a major role in immunologic tolerance within the gastrointestinal tract (45). Expression of CD103 and retinoic acid together induce gut $\mathrm{T}$ cells to express the gut-homing receptors CCR9 and $\alpha 4 \beta 7(44,46)$. CCR9 and its CCL25 ligand regulate recruitment of lymphocytes to the vasculature of the small intestine (47), while $\alpha 4 \beta 7$ integrin expression confines extravasation of these $\mathrm{T}$ cells to the intestinal post-capillary venules (48). Retinoic acid and TGF $\beta$ together promote the differentiation of Foxp $3^{+}$Treg from naive T cells (39), while retinoic acid further reinforces tolerance by dampening Th17 cell differentiation (49). Retinoic acid also fosters B cell isotype switching to IgA antibodies as well as their expression of CCR9 and $\alpha 4 \beta 7$ (50-52), and thereby contributes further to local tolerance responses.

\section{PULMONARY DENDRITIC CELLS}

Pulmonary dendritic cells can be differentially positioned in either the conducting airway or the interstitium of the lung $(15,53)$. In mice, CD11 $\mathrm{c}^{\text {hi }}$ myeloid cells are found in both compartments, while $\mathrm{CD} 11 \mathrm{c}^{-}$cells are reportedly confined to the airway mucosa (53). The airway dendritic cells form a prototypical network of interdigitating cells positioned beneath the epithelium (54-56), with many of these cells extending dendritic processes into the airway lumen to sample airway antigens (57), just as occurs in the gut (37). In mice these airway cells express $\mathrm{CD} 11 \mathrm{c}^{+}, \mathrm{MHCII}^{+}$,

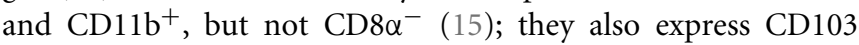
and tight junction proteins (claudin-1 and - 7 , and zonula occludens protein 2), which would play important roles vis-à-vis their positioning within the epithelium (43). After airway antigen sampling and processing, these cells can activate cognate $\mathrm{T}$ cells in their immediate environment $(57,58)$, but also migrate to the lung-draining lymph nodes where they present to $\mathrm{T}$ cells in that compartment (58). In rats the airway-associated dendritic cells are somewhat more heterogeneous (53). Bronchoalveolar lavage (59) and tissue digest (60) studies of the human lung have revealed three populations of dendritic cells, including $\mathrm{CD} 11 \mathrm{c}^{+} \mathrm{CD} 1 \mathrm{c}^{+}$and CD $11 \mathrm{c}^{+} \mathrm{BDCA}^{-} 3^{+}$myeloid cells, and $\mathrm{CD} 11 \mathrm{c}^{-} \mathrm{BDCA}-2^{+}$plasmacytoid dendritic cells, and these are considered analogous to the $\mathrm{CD}_{11 \mathrm{~b}^{+} \mathrm{CD} 103^{-} \text {and } \mathrm{CD} 1 \mathrm{~b}^{-} \mathrm{CD} 103^{+} \text {langerin }}{ }^{+}$conventional and plasmacytoid dendritic cell subsets, respectively, in mice (61). Further analysis in chronically inflamed (e.g., COPD) lung tissues have revealed langerin-positive and DC-SIGN-expressing dendritic cell sub-populations $(31,62)$ that were proposed to represent the human equivalent of the murine $\mathrm{CD}_{11 \mathrm{~b}^{-}} \mathrm{CD} 103^{+}$langerin ${ }^{+}$ and monocyte-derived inflammatory dendritic cells, respectively $(31,62)$. The $\mathrm{CD}_{103^{+}}$dendritic cells that comprise the bulk of the dendritic cells found in the lung-draining lymph node migrate there from the lung mucosa under the influence of lymph node-homing chemokines that signal via the CCR7 (43). In humans, the lung plasmacytoid dendritic cells express CD123 and BDCA-2, while the mouse plasmacytoid dendritic cell is

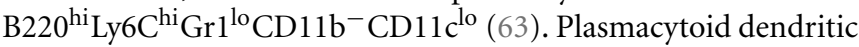
cells, which contribute importantly to tolerance responses to 
innocuous airway antigens (64), also express CD45RA, Ly49Q, BST2/tetherin [or murine plasmacytoid dendritic cell antigen (mPDCA)], sialic acid-binding immunoglobulin-type lectin (siglec)-H, inducible costimulator ligand (ICOS-L), programed death 1 ligand (PD-L)-1, and IDO (65), but produce copious amounts of IFN $\alpha$ in response to viral challenge (66). Under tolerogenic conditions, the $\mathrm{CD}_{103}{ }^{-}$and $\mathrm{CD}_{103}{ }^{+}$dendritic cells reportedly are specialized in presenting antigen to $\mathrm{CD} 4^{+}$versus $\mathrm{CD}^{+} \mathrm{T}$ cells, respectively $(67,68)$. However, under viral challenge the $\mathrm{CD}_{103}{ }^{+}$dendritic cells efficiently migrate to the draining lymph nodes where they cross-present viral antigens to $\mathrm{CD}^{+}{ }^{+} \mathrm{T}$ cells, while the $\mathrm{CD} 103^{-}$cells tend to remain within the lung parenchyma, where they present to $\mathrm{CD} 4^{+} \mathrm{T}$ cells in a proinflammatory manner $(67,68)$. This separation of function is also observed in asthmatic animals, wherein the CD103- dendritic cells present allergen to parenchymal $\mathrm{CD}^{+}{ }^{+} \mathrm{T}$ cells, while the $\mathrm{CD} 103^{+}$ subset presents allergen in the draining lymph node (69).

It is clear that the pulmonary dendritic cell contributes not only to the induction of asthma, but also to allergen-tolerance. Wholesale depletion of $\mathrm{CD}_{11 \mathrm{c}^{+}}$cells abolishes disease onset following allergen exposure in experimental animals (70), but plasmacytoid dendritic cell depletion in animals challenged with otherwise innocuous aeroallergens leads to development of allergen-specific asthmatic responses (64). Steady-state plasmacytoid dendritic cells express an immature/semi-mature phenotype, with low levels of MHCII and co-stimulatory molecules and intermediate levels of PDL-1 $(15,71)$, which would contribute to their tolerogenic phenotype, but IDO expression by these cells also strongly inhibits T cell proliferative responses (72). Nevertheless, $\mathrm{CD}_{103^{+}}$dendritic cells from the lungs of allergen-tolerant mice would also affect tolerance, inasmuch as they express RALDH and secrete retinoic acid, which contributes together with TGF $\beta$ to local induction of Foxp $3^{+}$regulatory T cells (73). Finally, it is important to note the contributions of other populations within the lung to tolerance. Tissue-resident (74) and alveolar (75) macrophages both express TGF $\beta$ and RALDH under steady-state conditions, such that they can also induce $\mathrm{CD} 4^{+} \mathrm{T}$ cells to which they present innocuous antigens to convert into Foxp $3^{+}$Treg. Alveolar macrophages can also suppress the immunostimulatory properties of steady-state lung-resident dendritic cells (76) and thereby further contribute to steady-state tolerance in the lung.

\section{CUTANEOUS DENDRITIC CELLS}

As with the intestinal tract and lungs, the skin is constantly exposed both to pathogens, which require induction of protective Teff responses, and to innocuous environmental agents for which tolerance is the desired outcome. There are at least three subsets of skin-derived dendritic cells, including the selfrenewing epidermal langerin ${ }^{+} \mathrm{CD}_{103}{ }^{-}$Langerhans cell (77), and the langerin ${ }^{+} \mathrm{CD} 03^{+}(78,79)$ and langerin ${ }^{-} \mathrm{CD}^{+} 03^{-}(80)$ dermal subsets; others have reported that the dermis contains five distinct subsets of dendritic cells (81). The epidermal Langerhans cell is probably the best known dendritic cell - as in other interfaces with our environment, these superficial cells form a contiguous network of interdigitating cells that are well positioned to detect and respond to cutaneous insults (82). In general, skin dendritic cells that acquire local antigens for lymph node presentation downregulate their E-cadherin epithelial receptors and upregulate CCR7, thereby acquiring responsiveness to chemokines expressed in the $\mathrm{T}$ cell zones of the draining lymph nodes (e.g., CCL19, CCL21) (14). In the lymph node, the dendritic cell presents its processed antigen peptides to the $\mathrm{T}$ cell, along with its co-stimulatory and polarizing signals. In addition, vitamin D3 metabolites expressed by the antigen-presenting dendritic cell induces $\mathrm{T}$ cell upregulation of CCR10, the receptor for the skin-homing chemokine CCL27 (22).

Langerin $^{+}$migratory skin dendritic cells (i.e., $\mathrm{CD} 103^{+}$dermal dendritic cells and Langerhans cells) can promote $\mathrm{T}$ cell tolerance responses to self antigens (83). The Langerhans cell appears to be unique in some respects, however, such that exposure to potent inflammatory adjuvants by itself does not override their innate tolerogenicity (84), perhaps in part because they do not express a number of important microbial pattern recognition receptors (e.g., TLR2, TLR4, or TLR5) (85). They are also unique in that, even while in a tolerogenic mode, they strongly express APC costimulatory markers and express IL-12. Nevertheless they fail to effectively activate NF- $\kappa$ B (i.e., translocate RelB into the nucleus) following adjuvant exposure (84), which is critical to induction of the immunostimulatory phenotype in dendritic cells (86). While dermal dendritic cells can effectively induce anti-bacterial immune responses, and would need to do so in situations where microbial organisms successfully penetrate the epithelial barrier, the default function of the Langerhans cell instead leads to regulatory $\mathrm{T}$ cell responses, perhaps as a means of preventing the integrity of the epidermal barrier from being compromised (85). Indeed, Langerhans cell depletion (e.g., by UV-B light exposure) has long been recognized to augment pathology in multiple contact sensitivity settings $(87,88)$. The Langerhans cell is efficient at capture and presentation of contact irritants, but this process can culminate in anergy and/or deletion of responding $\mathrm{CD} 8^{+} \mathrm{T}$ cells, with induction of $\mathrm{ICOS}^{+} \mathrm{CD}^{+}{ }^{+}$Foxp $3^{+}$regulatory $\mathrm{T}$ cell responses (89). The resident $\mathrm{CD}_{141^{+}}$dermal dendritic cell in humans can also effect tolerance through their expression of the inhibitory receptor ILT3 and of IL-10, which together upregulate $\mathrm{CD}^{+} 5^{+}$regulatory $\mathrm{T}$ cells that protect against allograft rejection (90). Migratory $\mathrm{CD} 103^{+}$langerin ${ }^{+}$dermal dendritic cells can also induce CD $25^{+}$Foxp $3^{+}$Treg outgrowth from naïve T cells, at least in part through their expression of TGF $\beta$ (91).

\section{HEPATIC DENDRITIC AND OTHER TOLERANCE-PROMOTING CELLS}

It is well recognized that operational tolerance occurs more frequently with liver transplants than with other organs, suggesting that this organ may have a unique tolerogenic capacity (92). Human liver dendritic cells comprise most prevalently BDCA-1 ${ }^{+}$ DC that, unlike blood dendritic cells, secrete substantial amounts of IL-10 on TLR ligation, and this contributes to their high level induction of $\mathrm{CD} 25^{+}$Foxp $3^{+}$Treg (11). It has also been reported that, in the steady state, hepatic myeloid and plasmacytoid dendritic cells can both induce tolerogenic $T$ cell responses, although by distinct mechanisms - the myeloid cells express a mature phenotype and produce high levels of regulatory factors such as IL-10, IL-27, retinoic acid, and prostaglandin E2 (93-96), whereas hepatic plasmacytoid dendritic cells express a more immature phenotype and secrete high levels of IL-10 $(97,98)$. The non-parenchymal 
hepatic stellate cell, the major storage site for retinol in the body (99), would potentially also play a role in hepatic tolerance through provision of retinoic acid and thereby by-stander contributions to hepatic regulatory $\mathrm{T}$ cell induction $(100,101)$. Another factor to consider in hepatic tolerance is the resident liver macrophage, the Kuppfer cell. Kuppfer cells are present in very large numbers in the liver and express MHCII and co-stimulatory molecules, although as quiescent cells they only poorly present antigen. Nevertheless, just as the hepatic stellate cells are a rich source of retinoic acid, Kuppfer cells constitutively express abundant prostaglandin E2 and 15d-prostaglandin J2, which strongly inhibit $\mathrm{T}$ cell responses to immunostimulatory dendritic cells (102). Thus, there are multiple mechanisms that may contribute to the innate tolerogenic phenotype of the liver.

\section{EXPERIMENTAL APPLICATION OF TOLEROGENIC DENDRITIC CELLS \\ STEADY-STATE AND IMMATURE DENDRITIC CELLS}

For practical reasons it is unlikely that steady-state dendritic cells freshly purified from donor tissues would be used clinically, but investigations into such cells have provided substantial insights into the immunobiology of tolerogenic dendritic cells. Steady-state dendritic cells from lymphoid organs $(103,104)$ and non-inflamed tissues $(91,104,105)$ express a relatively immature phenotype - in general, such cells are tolerogenic $(105,106)$. For example, treatment with small numbers of antigen-pulsed steady-state CD8 $\alpha^{+}$ splenic dendritic cells can induce asthma tolerance in mouse models, reversing the asthmatic animals' bronchial hyperresponsiveness and airway eosinophil and Th2 cytokine recall responses to allergen challenge; expression of IL-10, TGF $\beta$, and IDO, as well as direct dendritic cell-Teff cell contact each contribute to the tolerogenic activities of these cells (107). It is important to their activity that such steady-state dendritic cells remain quiescent while being purified or manipulated ex vivo, as even overnight exposure of $\mathrm{CD} 8 \alpha^{+}$dendritic cells to GM-CSF, for example, converts them into potent inducers of cytotoxic $\mathrm{CD}^{+} \mathrm{T}$ cell responses (108). Steady-state $\mathrm{CD} 8 \alpha^{+}$dendritic cell signaling leads to attenuated IL-2 expression by T cells and increased apoptosis, at least in part through the dendritic cell's expression of FasL (109-111).

Tissue dendritic cells that acquire antigens in situ in such a way that they do not become activated also remain tolerogenic. Thus, as noted, steady-state airway mucosal dendritic cells routinely migrate to the draining lymph nodes and present innocuous allergens in a tolerogenic fashion - indeed, this is the default mechanism by which $\approx 80 \%$ of the human population remains allergen-tolerant (112). Similarly, targeting antigens to dendritic cells with anti-DEC205, for example, does not activate the cells and thus leads to antigen-specific tolerance in multiple models (113115). And dendritic cells that phagocytose apoptotic cells remain in a largely quiescent state and thus are also tolerogenic $(116,117)$, at least in part via induction of TGF $\beta$ expression in the draining lymph nodes with consequent activation of Foxp $3^{+}$Treg (118).

There is also a large body of data regarding the tolerogenic properties of immunologically immature dendritic cells that have been generated in vitro from bone marrow or blood of mice or humans. These cells tend to express low levels of MHCII and co-stimulatory markers and have thus been thought of as largely ineffective in activating $\mathrm{T}$ cells through the classical TCR signaling pathways (119-122), although it has also been suggested that PD-L1 and PD-L2 expression by these cells contributes to their tolerogenic activities $(123)$. There are $\approx 100$ genes that are differentially expressed in immature versus immunostimulatory mouse bone marrow-derived dendritic cells, including a number of cytokines (e.g., Flt3L, TNF), chemokines (e.g., MIP2, RANTES), chemokine receptors (e.g., CCR2, CCR5), and other (e.g., RP105, Ax1) markers (124). Passive transfer of antigen-pulsed immature dendritic cells has been shown to induce tolerance either in vivo or in vitro in numerous experimental models and with human cells (125-132). An important caveat with use of immature dendritic cells to treat overtly inflammatory conditions is that the pro-inflammatory environment they face in vivo can activate these cells, such that they activate pathogenic (e.g., Th1, Th17) as opposed to regulatory $\mathrm{T}$ cell responses $(133,134)$, as discussed below.

\section{INDUCED TOLEROGENIC DENDRITIC CELLS}

Some of the first insights into the induction of a tolerogenic phenotype within dendritic cells arose from the studies of Langerhans cells that had been exposed to either ultraviolet B radiation (8) or IL-10 $(8,9)$. Dendritic cells from IL-10-expressing melanoma tumors (135) and IL-10-exposed immature monocyte-derived dendritic cells (136) were then also shown to be tolerogenic. This potential for using tolerogenic cells, whether dendritic cells or subsequently induced regulatory $\mathrm{T}$ cells, to dampen pathogenic responses has burgeoned into a field of immunology into itself. We now know that a large array of mediators can induce a tolerogenic phenotype within dendritic cell populations. These include IL-10 (9, 30, 33, 135-149) and other cytokines (150-158), corticosteroids (143, 159-162), vitamin D3 (160, 163-172), rapamycin (143, 160, 173-175), and neuropeptides (176, 177) (Table 1), each of which we will discuss. Although we will not discuss the following populations, it has been reported that dendritic cells can also be rendered tolerogenic by exposure to: anti-CD3 (178); Aspergillus oryzae protease (162); aspirin (179); atorvastatin (180); butyric or mycophenolic acids (181); the $\alpha 7 \beta 0$ isoform of C4bbinding protein (182); the FasL decoy receptor, decoy receptor-3 (183); galectin-1 (184, 185); growth-related oncogene (GRO)gamma (186); intravenous immunoglobulin (IVIg) (187, 188); protein kinase C inhibitors (189); or retinoic acid (190-193), or by inhibition of miRNA let-7i (194). IL-10-, vitamin D3-, dexamethasone-, and rapamycin-induced tolerogenic dendritic cells stand out as populations that have had been particularly well-studied in mouse and/or human systems, so we will concentrate our discussions on these cells, with the interested reader referred to the cited reports for these alternate populations. Furthermore, given the potential ethical issues with use of dendritic cells transfected with viruses that express tolerogenic molecules (e.g., IL-10, CTLA4Ig) or that suppress stimulatory molecules (e.g., co-stimulatory, immunostimulatory, or pro-apoptotic molecules, such as CD80, IL-12, or TRAIL, respectively (195)), we will not devote significant discussion to these approaches at this time.

\section{INTERLEUKIN-10-INDUCED REGULATORY DENDRITIC CELLS}

As noted, IL-10 was one of the first mediators shown to induce human dendritic cells to adopt a tolerogenic phenotype $(8,9,122$, 
Table 1 | Phenotypes of human tolerogenic dendritic cells differentiated using different agents.

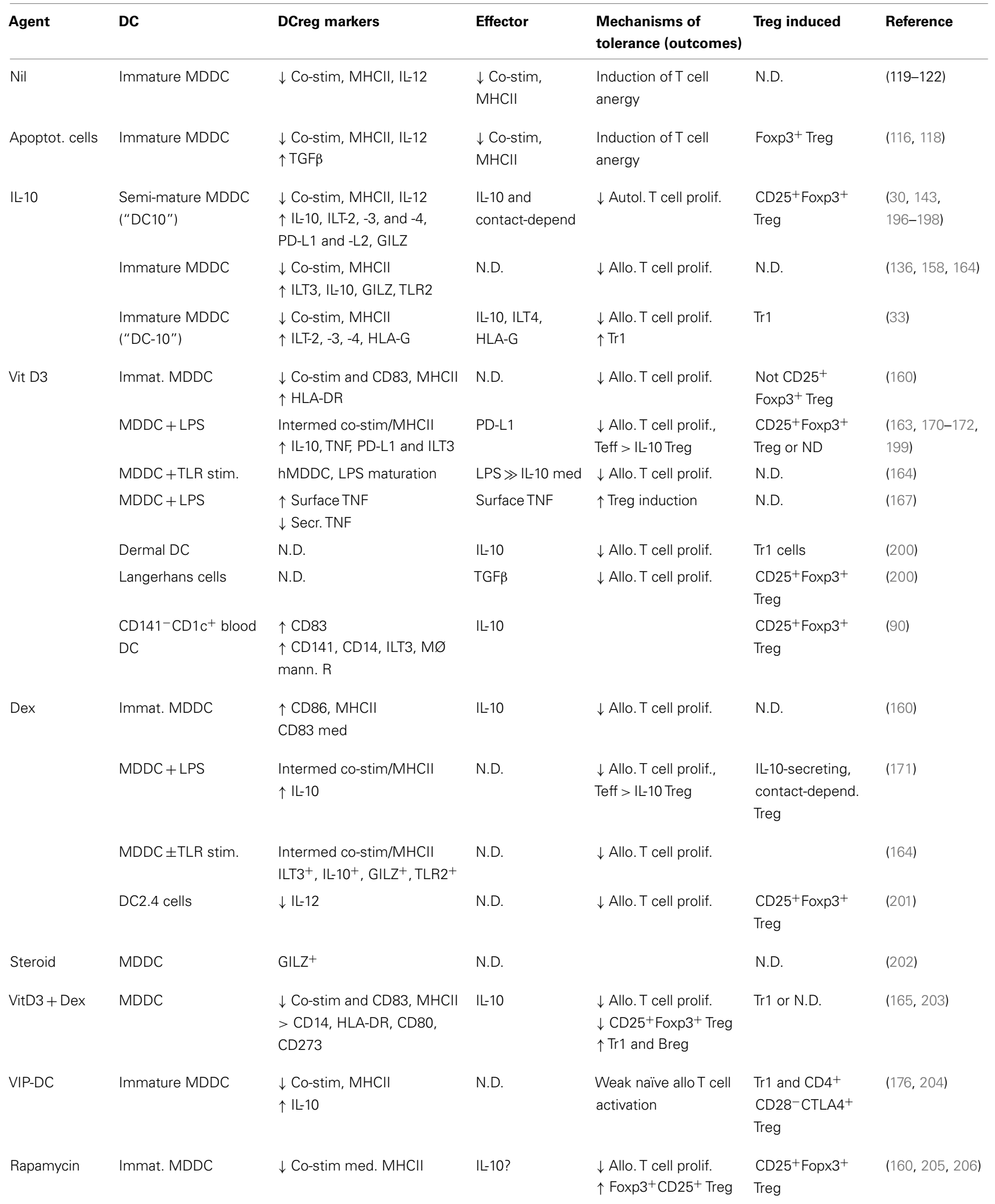


$135,136,141,148,150,209-212)$. These reports together indicated that IL-10-differentiated monocyte-derived dendritic cells display reduced levels of MHCII and co-stimulatory markers, and can induce Teff cell anergy. Sometime later it was shown that IL-10-induced semi-mature CD14 ${ }^{+}$monocyte-derived dendritic cells (DC10) from atopic asthmatic individuals suppress specific allergen-driven proliferative and Th2 cytokine responses of autologous peripheral blood CD $4^{+} \mathrm{CD} 25^{-/ 1}$ Foxp $3^{-}$Teff cells, and convert these Teff cells into regulatory $\mathrm{T}$ cells (30). The maturation status of these DC10 was attributable to their exposure during differentiation to a stimulatory cocktail containing IL-1 $\beta$, TNF, IL-6, and PGE2, in addition to IL-10 (30), but these cells are resistant to further, LPS-induced, maturation (209). DC10 express low levels of MHCII, co-stimulatory markers, 4-1BBL and OX40L, but they strongly express DEC205, IFN $\alpha 1$, CCR7, ILT2 (an inhibitory HLA-G receptor), as well as IL-10 (Table 2). They induce Teff cells to differentiate into IL-10-secreting $\mathrm{CD} 25^{+}$Foxp $3^{+}$LAG$3^{+} \mathrm{CTLA}^{+}{ }^{+}$regulatory $\mathrm{T}$ cells, which in turn suppress allergendriven responses of autologous Teff cells in a contact-dependent fashion (30). Others found that similar semi-mature IL-10differentiated dendritic cells express high levels of ILT3, ILT4, PD-L1, and PD-L2, that they (but not immature cells) respond strongly to the lymph node-homing chemokine CCL19 (143), and that they induce regulatory $\mathrm{T}$ cells that also suppress allogeneic $\mathrm{T}$ cell responses in a contact, but not IL-10- or TGF $\beta$-dependent fashion (196). These DC10 also express glucocorticoid-induced leucine zipper (GILZ), which is both necessary and sufficient for expression of IL-10, ILT3, and PD-L1 by these cells - GILZ silencing eliminates their tolerogenic activities (197, 198). IL-10differentiated human monocyte-derived dendritic cells that have never been exposed to maturation-inducing agents are also tolerogenic $(33,148,212)$. As noted above, a minor population of IL-10producing circulating dendritic cells, called DC-10, was recently identified in humans (33), and those investigators also generated an analogous population of immature IL-10-differentiated dendritic cells (DC-10) that similarly express IL-10 (Table 2), as well as the inhibitory receptors ILT2, ILT3, ILT4, and HLA-G (33). Others have noted that such cells also express signaling lymphocyte activation molecule (SLAMF1, CD150) (148), which inhibits CD40-mediated signal transduction (213), and would therefore interfere with two-way dendritic cell-T cell conversations. These cells have been reported to suppress Teff cell responses in a manner that is contact-dependent, and independent of any role for secreted soluble mediators (148), although others note that IL-10 secretion and cell-surface inhibitory receptors are both important to the regulatory activities of such immature IL-10-differentiated dendritic cells (33). It is very intriguing that exposure of semimature human dendritic cells to IL-10 leads to their induction of classical CD25 ${ }^{+}$Foxp3 ${ }^{+}$Treg $(30,196)$, while exposure of immature human dendritic cells to IL-10 leads to induction of Foxp3 ${ }^{-}$ $\operatorname{Tr} 1$ cells (33). It will be interesting to determine whether exposure of such immature regulatory dendritic cells to inflammatory (i.e., maturation-promoting) conditions would qualitatively or quantitatively affect their immunobiology.

Murine DC10 can prevent the onset of asthma in experimental mice, as well as reverse the asthmatic phenotype in severely affected animals $(137,138,140,214-216)$, just as do dendritic cells that have been virally transfected to express very high levels of IL-10 (146). These DC10, which are not exposed to maturational stimuli during differentiation, display low levels of cell-surface MCHII and co-stimulatory markers, are avidly phagocytic and chemotactically responsive to MIP- $1 \alpha$, and express elevated levels of IL-10, TGF $\beta$ (137, 138, 215), and PD-L1 (Li et al., unpublished observation). They are highly effective therapeutically in mouse models of ovalbumin (OVA) - (138, 140, 214-216) and house dust mite - (137) asthma. In both settings, DC10 abrogate airway hyperresponsiveness (AHR) within 3 weeks of treatment and dampen the allergic Th2 phenotype

Table 2 | Impact of phenotype on the levels of IL-10 secretion by regulatory dendritic cells.

\begin{tabular}{|c|c|c|}
\hline Differentiating agent & DC (IL-10 levels) & Reference \\
\hline \multicolumn{3}{|c|}{ NON-REGULATORY DENDRITIC CELLS } \\
\hline TNF & Semi-mature MDDC ( $\approx 35 \mathrm{pg} / \mathrm{ml})$ & $(30)$ \\
\hline \multicolumn{3}{|c|}{ TOLEROGENIC DENDRITIC CELLS } \\
\hline Vitamin D3/dexamethasone & MDDC (9ng/ml) & (203) \\
\hline Galectin-1 & MDDC (LPS, $\approx 500 \mathrm{pg} / \mathrm{ml})$ & $(185)$ \\
\hline \multirow[t]{4}{*}{ Vitamin D3 } & Dermal DC (CD40L, $\approx 300-700$ pg/ml) & $(90)$ \\
\hline & MDDC (unstim or LPS, $\approx 100 \mathrm{pg} / \mathrm{ml}$ ) & $(160,164)$ \\
\hline & MDDC (LPS or CD40L, $\approx 2$ ng/ml) & $(167)$ \\
\hline & MDDC (CD40L, 4 ng/ml) & (163) \\
\hline Rapamycin & MDDC (unstim or LPS, 50-100 pg/ml) & $(143,160)$ \\
\hline TGF $\beta$ & MDDC (unstim, $200 \mathrm{pg} / \mathrm{ml} ;$ LPS, $\approx 2 \mathrm{ng} / \mathrm{ml}$ ) & $(143,158)$ \\
\hline
\end{tabular}


in an allergen-specific fashion $(137,138,140,215)$. This suppression of allergen-induced airway eosinophil and Th2 cytokine responses and circulating allergen-specific IgE and IgG1 levels is progressive, such that at 8 months after a single DC10 treatment these parameters are at near background levels (138), although four DC10 treatments bring the asthma phenotype to near background within 2 months (138). Cell tracking studies indicate that DC10 that are delivered intraperitoneally accumulate maximally in the lungs and lung-draining lymph nodes within 1 week, but few, if any, DC10 can be detected within any anatomic compartment at 3 weeks post-treatment (214). This indicates that while tolerance induced by DC10 is long-lived, most of its impact is realized only after the treatment cells have disappeared from the body. That is consistent with the observation that DC10 treatments induce $\mathrm{CD} 4{ }^{+} \mathrm{CD} 44^{\text {hi }} \mathrm{CD} 69^{\text {hi }} \mathrm{CD} 62 \mathrm{~L}^{\text {lo }} \mathrm{CD} 25^{\text {lo }} \mathrm{Foxp} 3{ }^{-}$Teff cells to transdifferentiate into $\mathrm{CD} 4{ }^{+} \mathrm{CD} 25^{+}$Foxp $3^{+}$Treg, with maximal Treg activation occurring at 3 weeks after DC10 treatment (215). Human DC10-induced CD $25^{+}$Foxp $3^{+}$Treg express LAG3 and CTLA3 (30), while the analogous Treg in DC10-treated asthmatic mice express LAG3, cytotoxic T lymphocyte antigen-4 (CTLA4) (137, 215), ICOS, PD-1, GITR (215), and neuropilin1 , but lower levels of Helios (217). Infectious tolerance is also evident in these animals, as the endogenous pulmonary $\mathrm{CD} 11 \mathrm{c}^{+}$ dendritic cells of DC10-treated asthmatic animals also take on a regulatory phenotype ( $\mathrm{Li}$ et al., unpublished observation). While DC10 engage $\mathrm{CD}^{+}{ }^{+} \mathrm{CD} 25^{+}$Foxp $3^{+}$natural $(\mathrm{n})$ Treg in a productive fashion and these $\mathrm{T}$ cells have a modest role in the asthma tolerance within DC10-treated animals, DC10-induced $\mathrm{CD}_{25}{ }^{+} \mathrm{Foxp}^{+}$(i) Treg are many-fold more effective than naturally occurring CD $25^{+}$Foxp $^{+}$regulatory $\mathrm{T}$ cells (nTreg) of identical TCR specificity in suppressing the asthma phenotype (217).

IL-10 expression by immature or otherwise quiescent dendritic cells has been reported numerous times to be important to tolerance induced by these cells $(24,107,218)$, and DC10 (as well as DC-10) express yet higher levels of this regulatory cytokine $(30,33,137,138,140,215,216)$ (Table 2). Indeed, expression of IL-10 by DC10 is critical $(140,214)$ although not sufficient for tolerance induction, inasmuch as MHCII-knock-out DC10, which expresses otherwise therapeutic levels of IL-10, do not induce tolerance (214). Moreover, combined IL-10 and MHCII expression by DC10 is still not sufficient for full expression of tolerance - allergen-presenting CD80/CD86 double knock-out (214) or CD40-knock-out (W. Dawicki, H. Huang and J.R. Gordon, unpublished observations) DC10 still do not induce tolerance at levels equivalent to wild-type DC10 (214). This underscores that conversion of Teff cells to regulatory $\mathrm{T}$ cells by DC10 requires not only delivery of tolerogenic signals to the T cell, but also productive feedback from the engaged T cell to the DC10.

\section{VITAMIN D3-INDUCED REGULATORY DENDRITIC CELLS}

Vitamin D and its metabolites would appear to have a significant influence within the immune system, such that there is substantial evidence of an unrealized potential for its use in an array of immunologic disorders [reviewed in Ref. $(219,220)]$. It is clear that vitamin D3 can induce differentiation of tolerogenic dendritic cells (DC-VitD3) $(163,170,221,222)$. Addition of vitamin D3 to mouse bone marrow $(177,223,224)$ or human monocyte-derived $(164,170,172,225)$ dendritic cell cultures induces cells that express low levels of MHC II and co-stimulatory molecules, and produce IL-10 instead of IL-12 (Table 2). Semimature monocyte-derived DC-VitD3 express augmented levels of TNF and PDL-1, and this PDL-1 is reportedly critical to their induction of IL-10-expressing contact-dependent Treg (171), as is expression of membrane-bound TNF by these dendritic cells (226). As with IL-10-differentiated dendritic cells, DC-VitD3 only respond to the lymph node-homing chemokine CCL19 if they have been exposed to maturational stimuli (143). This again raises the question of whether such chemokine-dependent lymph node homing might reasonably be expected to contribute, if not be critical, to the tolerogenic activities of regulatory dendritic cells. Addition of vitamin D3 to cultures of human skin Langerhans cells leads to expression of TGF $\beta$ by these cells and thereby downstream induction of $\mathrm{CD} 25^{\text {hi }} \mathrm{CD} 127^{\mathrm{lo}} \mathrm{Foxp} 3^{+}$cells (i.e., classical inducible Treg) (200). It similarly induces CD141- CD1c ${ }^{+}$human blood dendritic cells to differentiate into IL-10-expressing dermal dendritic cell-like $\mathrm{CD} 141^{+} \mathrm{CD} 14^{+} \mathrm{ILT}^{+}$cells that induce development of CD $25^{\text {hi }}$ CTLA $4{ }^{+}$Foxp $3^{+}$Treg responses (90). In contrast, addition of vitamin D3 to cultures of human dermal dendritic cells upregulates expression of IL-10 and their induction of IL10-expressing Foxp $3^{-} \operatorname{Tr} 1$ cells (200). This highlights again that exposure of different dendritic cell populations to the same mediator can have very divergent outcomes in terms of the type(s) of regulatory $\mathrm{T}$ cells so induced. DC-VitD3 have been shown to be tolerogenic in vivo as well. Treatment of diabetic mice with pancreatic islet antigen-pulsed DC-VitD3 prior to pancreatic islet transplantation significantly decreases subsequent islet rejection (166), while sensitization of mice with H-Y antigen-pulsed DCVitD3 leads to prolongation of male skin grafts in female recipients $(177,223,224)$.

\section{DEXAMETHASONE-INDUCED TOLEROGENIC DENDRITIC CELLS}

The anti-inflammatory and immunosuppressive properties of corticosteroids have been known and employed clinically since their discovery some 75 years ago (227). While glucocorticoid treatments have significant clinical benefits in terms of suppressing inflammation, and it has been shown that they increase the numbers of $\mathrm{CD} 4{ }^{+} \mathrm{CD} 25^{\mathrm{hi}}$ cells and Foxp3 expression levels in multiple inflammatory settings, these increases are not necessarily associated with augmented Treg activity (228). Corticosteroids do induce immature dendritic cells to adopt a tolerogenic phenotype and thereby contribute to the anti-inflammatory properties of these agents $(159,229,230)$, but the fact that mature dendritic cells undergo apoptosis in response to in vitro or in vivo dexamethasone treatment suggests that its effects on dendritic cells are somewhat more complex (231). Dendritic cells that are differentiated in the presence of dexamethasone (DC-Dex) express low levels of co-stimulatory markers and MHC II, produce elevated levels of IL-10 and less IL-12 (159, 161, 164, 171, 229, 230, 232), and express modestly elevated levels of ILT2 (198) and ILT3, but high levels of GILZ (164). As with semi-mature IL10-differentiated dendritic cells, GILZ expression by DC-Dex is critical to their expression of IL-10, ILT3, and B7-H1/PDL-1 (197); both populations also maintain their immunosuppressive phenotype even after stimulation with TLR4 agonists $(209,233,234)$. 
The similarities between DC10 and dexamethasone-conditioned dendritic cells extends further - dexamethasone-exposed DC2.4 dendritic cells also induce Foxp $3^{+}$Treg differentiation in vitro (201), while use of DC-Dex immunotherapy for experimental corneal allografts similarly leads to increased tissue levels of intragraft Foxp $3^{+} \mathrm{T}$ cells, reduced levels of graft inflammatory cell infiltrates, and prolonged graft survival (235). And others have reported that repetitive stimulation of T cells with DC-Dex induces the $\mathrm{T}$ cells to adopt a contact-dependent regulatory $\mathrm{T}$ cell phenotype (171). DC-Dex treatment of murine recipients of MHC-mismatched heart transplants leads to delayed rejection of the allografts (234) although, oddly, DC-Dex treatments reportedly accelerate antibody-mediated graft rejection responses to transplanted MHC-mismatched pancreatic islets in rats (236). Interestingly, the contact-dependent regulatory $\mathrm{T}$ cells induced by DC-Dex, but not those induced by DC-VitD3, reportedly suppress T cell responses in an antigen-independent fashion (171), although others have shown that, as a general feature, activated regulatory $\mathrm{T}$ cells readily suppress by-stander Teff cell responses $(237,238)$.

\section{VITAMIN D3 AND DEXAMETHASONE-INDUCED TOLEROGENIC DENDRITIC CELLS}

While vitamin D3 and dexamethasone each can induce a tolerogenic phenotype in dendritic cells, some investigators have further assessed the regulatory activities of cells generated in the presence of both vitamin D3 and dexamethasone (DC-Dex/VitD3). DCDex/VitD3 produce much high levels of IL-10 (i.e., $9 \mathrm{ng} / \mathrm{ml}$ ) (203) than either DC-VitD3 or DC-Dex (i.e., 0.1-4 ng/ml) (Table 2) $(143,159,160,163,164,167,198)$, and thus display a higher IL10/IL-12 expression ratio and poorly stimulate allogeneic T cell proliferation responses (165). They reportedly cannot effectively prime naïve CD8 $\mathrm{T}$ cells but, interestingly, while a single DCDex/VitD3 treatment drives expansion of memory CD8 T cells, any subsequent DC-Dex/VitD3 exposure leads to collapse of the CD8 ${ }^{+}$ T cell populations (239). DC-Dex/VitD3 have been shown to be somewhat effective in suppressing colitis pathology in a mouse model, apparently also in an antigen-independent manner (240).

\section{NEUROPEPTIDE-INDUCED TOLEROGENIC DENDRITIC CELLS}

Vasoactive intestinal peptide (VIP) is a 28-amino acid immunomodulatory neuropeptide that binds to B-class Gprotein-coupled receptors such as the VPAC1 and VPAC2 (241, 242). VIP treatments induce regulatory T cell responses in experimental animals and with human Teff cells (243). For example, VIP treatment of mice with TNBS-induced colitis induces tolerance responses, dampening TLR2- and TLR4-induced inflammation and increasing expression of Foxp3 and TGF $\beta$ (244), as it does in a rat model of collagen-induced arthritis (245). But VIP can act directly on the Teff cells - culture of CD25- Foxp3 ${ }^{-}$ Teff with VIP induces their differentiation into $\mathrm{CD} 25^{+}{ }^{+}$Foxp $3^{+}$ Treg that express high levels of IL-10 and CTLA4 and are protective in a mouse model of graft versus host disease (GVHD) (246). Nevertheless, VIP can also induce dendritic cells to adopt a regulatory phenotype and thereby affect tolerance by this means. Differentiation of human dendritic cells in the presence of VIP (DC-VIP) or the neuropeptide pituitary adenylate cyclaseactivating polypeptide (PACAP) induces the development of cells that secrete of high levels of IL-10, and strongly induce regulatory $\mathrm{T}$ cell responses. DC-VIP treatments dampen pathology in a number of experimental settings, including experimental allergic encephalomyelitis (EAE), rheumatoid arthritis (247), bone marrow transplant-induced GVHD (248), and colitis (249). While a number of reports indicate that DC-VIP induce $\operatorname{Tr} 1$ phenotype regulatory cells, as determined by secretion of IL-10/TGF $\beta$, but not IFN $\gamma$, IL-2, IL-4, or IL-5 (204, 250-252), other reports indicate that DC-VIP instead induce $\mathrm{CD} 4{ }^{+} \mathrm{CD} 25^{+}$Foxp $3^{+}$Treg responses (253-255) in some of the same model systems. DCVIP can also induce IL-10-secreting CD28 ${ }^{-} \mathrm{CTLA}^{+} \mathrm{CD} 8^{+}$Treg $(176,252)$. VIP-secreting VIP-lentivirus-transfected DC are similarly tolerogenic in mouse models of acute and chronic EAE and cecal ligation-and-puncture sepsis (177). It has been speculated that DC-VIP would be more effective therapeutically when targeting Th1 rather than Th2 responses (176), ostensibly because VIP skews Th1 or Th17 T cells to a Th2 phenotype (256). This raises an important question in dendritic cell immunotherapeutics, and that is whether the specific type of regulatory cell to be employed (e.g., DC-Dex versus DC-VIP) needs to be carefully matched with, for example, the Th1, Th2, or Th17 nature of the target disease in order to ensure optimized outcomes.

\section{RAPAMYCIN-INDUCED TOLEROGENIC DENDRITIC CELLS}

Rapamycin is a macrolide immunosuppressive agent that dampens dendritic cell maturation through binding to the serine/threonine protein kinase mammalian target of rapamycin (mTOR). Signaling via mTOR has broad-ranging effects in many systems, including the nervous system, nutrition, and others, where it regulates cell growth, proliferation, motility, and survival (257). Antigen recognition by naïve $\mathrm{CD} 4^{+}$and $\mathrm{CD} 8^{+}$T cells activates $\mathrm{mTOR}$ and thereby fosters cellular progression to a committed Foxp $3^{-}$Teff phenotype (205), while suppression of mTOR with rapamycin leads instead to induction of fully functional CD25 $5^{+}$Foxp $3^{+}$ Treg (258). Thus it was reported some time ago that rapamycin increases the regulatory activities of $\mathrm{CD} 4^{+} \mathrm{CD} 25^{+}$Foxp $3^{+}$Treg (206). Clinically, rapamycin has been widely used to prevent allograft rejection, particularly in renal transplant patients (206), although the potential for rapamycin-related adverse cutaneous manifestations in these patients has limited its broad applicability (259). Rapamycin affects both T cells and dendritic cells, although it displays divergent effects on myeloid and monocyte-derived dendritic cells, augmenting the allostimulatory capacity of the former cells but markedly dampening the immunostimulatory phenotype of monocyte-derived dendritic cells (260). In experimental systems rapamycin treatments impair Flt3L mobilization of murine dendritic cells, their upregulation of co-stimulatory molecule and inflammatory cytokine expression, and their allostimulatory activity (261), even after exposure to activating agents such as LPS or anti-CD40 (262). Mouse dendritic cells that are differentiated in the presence of rapamycin (DC-Rap) induce naïve T cells to differentiate into CD $25^{+}$Foxp $3^{+}$Treg (263). Moreover, such DC-Rap enhance apoptotic death among alloreactive CD8 T cells (264), further contributing to the tolerance response of transplant recipients. DC-Rap treatment of murine heart transplant recipients similarly induces outgrowth within the transplants of Foxp $3^{+}$ Treg and, as a consequence, long term organ survival (262), just 
as has been shown in numerous other studies $(173,206,261,262$, 265, 266).

\section{IMPACT OF DELIVERY ROUTE AND INFLAMMATION ON THERAPEUTIC OUTCOMES SELECTING THE CORRECT DELIVERY ROUTE FOR TOLEROGENIC DENDRITIC CELLS}

Not all routes for delivery of tolerogenic dendritic cells will necessarily provide the desired outcomes. For example, we reported that CD45.2 $2^{+}$DC10 that are delivered intraperitoneally to congenic CD45.1 $1^{+}$mice with a severe asthma phenotype appear within the lungs and airways of recipient mice within 2 days of delivery, achieve maximal numbers in this compartment by 7 days and then wane thereafter. DC10 appear in the lung-draining (mediastinal) lymph node of these animals in lower numbers, but with approximately the same kinetics, and also in the spleen but not cervical nodes, MLNs, blood, bone marrow, or liver. Within 3 weeks of delivery the treatment cells are no longer detectable in the lungs or mediastinal lymph nodes (214), suggesting that the natural lifespan of such DC10 may be 2-3 weeks. We know that DC10 treatments correct $\sim 50 \%$ of the pathognomic bronchial hyperresponsiveness seen in asthma phenotype mice within 2 weeks of treatment and that by 3 weeks this airway response is completely normalized (138). Moreover, the time of maximal activation of regulatory $\mathrm{T}$ cells in the lungs of these animals is 3 weeks after DC10 delivery, but it was not determined whether the primary site within which the DC10 induce Teff cells to differentiate into regulatory $\mathrm{T}$ cells was in situ in the lungs or in the mediastinal lymph nodes (or both) (215). This remains an important, but unanswered question.

We also assessed the relative effects of intraperitoneal (i.p.), transtracheal (t.t.), subcutaneous (back skin; s.c.), or intravenous (i.v.) DC10 delivery to asthmatic animals and found that i.p. or t.t. delivery were equally effective, fully reversing bronchial hyperresponsiveness, and rapidly dampening airway eosinophil and Th2 cytokine responses to allergen challenge and circulating allergenspecific IgE and IgG1 levels (138). The s.c. DC10 treatments dampened the airway recall responses to allergen challenge, but not bronchial hyperresponsiveness, nor did they significantly reduce systemic IgE levels (138). On the other hand, multiple investigators have reported that s.c. delivery of tolerogenic dendritic cells is protective in rat models of EAE (267-271), which suggests that the anatomic site of the target pathology in immunotherapeutic applications may be important in selecting the delivery route for the treatment dendritic cells. Intravenous delivery of DC10 has no discernible impact of the disease phenotype in a mouse model of asthma $(138,272)$ or a rat model of EAE $(271)$, but in mouse models of cardiomyopathy (147), experimental immune myocarditis $(149,273)$, and diabetes $(274,275)$ i.v. delivery of tolerogenic dendritic cells significantly reduces local pathology and induces tolerance. Similarly, i.v. infusion of DC-VitD/IL-10 in a rhesus macaque model of allogeneic kidney transplantation significantly prolonged survival relative to control animals (rapamycin/CTLA4Ig treatment, but no dendritic cells) (276). There has not been a sufficient number of comprehensive studies on the impact of the route of dendritic cell delivery on tolerance outcomes to generate specific guidelines at this point in time, but it does appear that the disease or compartment being targeted may be an important consideration. Certainly, we would expect that the cells should be migration-competent (i.e., express appropriate chemokine receptors), such that they are able to travel to the disease target site or its draining lymph nodes in order to best interact with the cognate Teff cells.

\section{USE OF TOLEROGENIC DENDRITIC CELLS IN INFLAMMATORY SETTINGS}

An important consideration in clinical use of tolerogenic dendritic cells, particularly when targeting inflammatory diseases (e.g., colitis, inflammatory bowel disease), is whether pre-existing adverse conditions that these cells might encounter after delivery can alter or ablate their tolerogenic activity. If so, could an inflammatory milieu convert the treatment dendritic cells into immunostimulatory populations that might exacerbate rather than ameliorate disease severity? While immature dendritic cells can have substantial tolerogenic activities, we know that exposure of these cells (133, 134) or even some populations of semi-mature dendritic cells (133, 134) to inflammatory environments can induce them to differentiate into potently immunostimulatory cells that augment disease severity. With this in mind, many investigators have assessed the impact of maturation-provoking $(30,90,143,165,197)$ or otherwise inflammatory $(163,164,167,170,171,177,222)$ signals on the tolerogenic phenotype of their differentiated dendritic cells. Dendritic cells express receptors for and can be activated by a number of pro-inflammatory cytokines (e.g., IL-1, TNF, IFN, TSLP) (277) and they can express numerous pattern recognition receptors [e.g., protease-activated receptors (PARs), TLR, C-type lectin receptors $(78,164,278-281)]$, retinoic acid-inducible gene-1 (RIG-1) and the melanoma differentiation-associated gene-5 (MDA-5) (281), through which they interact with microbial and non-microbial agents. For example, a number of "natural" allergens (e.g., house dust mite) trigger inflammatory responses through their abilities to activate cells via PAR2 $(282,283)$ or C-type lectin receptors such as DC-SIGN and dectin-2 (284), while TLR signaling can potently activate expression of inflammatory signals by immature or mature dendritic cells. There have been a number of excellent reviews that address the expression of TLR by human and mouse dendritic cells [e.g., Ref. (281)], such that we will not address this issue herein.

Toll-like receptor signaling within tolerogenic dendritic cell populations does not always have a detrimental outcome. For example, BDCA- $1^{+}$human liver dendritic cells secrete substantial amounts of IL-10 on TLR ligation, and this contributes to their high level induction of $\mathrm{CD}_{2} 5^{+} \mathrm{Foxp}^{+}$Treg (11). Human DC10, DC-Dex, and DC-VitD express the same panel of TLR as monocyte-derived dendritic cells, such that all are responsive to Pam3CSK4, polyinosinic-polycytidylic acid, LPS, and flagellin (164), but the tolerogenic populations uniquely upregulate expression of TLR2 on TLR engagement (164). Moreover, TLR2 or TLR4 signaling in human DC-VitD3 and DC-Dex induces expression of the tolerance-promoting cytokines IL-10 and IL-27 (160, 285). Others have reported that human DC-Dex are refractory to challenge with an array of heat-killed gram-negative bacteria (e.g., Escherichia coli, Protheus mirabillis, Klebsiella pneumoniae, Salmonella thyphimurium) (286), while DC-Rap (160) and DC-VIP (252) are resistant to reversal of their tolerogenic phenotype by 
LPS challenge. Interestingly, while isolated LPS challenge induces an IL-12 response by immature monocyte-derived dendritic cells, simultaneous exposure of these cells to LPS and IFN $\gamma$ reportedly leads to a transient IL-12 response that is replaced within 24-48 h with a robust IL-10 response (287).

Finally, while we may well be able to design and generate tolerogenic dendritic cells that are resistant to reversal of phenotype by inflammatory environments, it is clear that the tolerance they induce is also dependent on transference of that phenotype to the regulatory $\mathrm{T}$ cells with which they interact. Moreover, infectious tolerance also involves the conversion of endogenous tissue dendritic cells into tolerogenic populations by the induced regulatory T cells $(226,288)$. Indeed, it has been suggested that a defect in such infectious tolerance processes may contribute to the development of an asthma phenotype in affected individuals (289). The desired outcome in dendritic cell immunotherapy is the induction of regulatory $\mathrm{T}$ cells that can reverse pathogenic Teff cell responses, but at least some populations of regulatory $\mathrm{T}$ cells can be converted into pathogenic Teff cells in the context of inflammatory environments - it has been shown that Foxp $3^{+}$Treg can convert to Th17 cells in animals with colitis $(290,291)$, but we seem to have only scant evidence regarding the extent to which other populations of regulatory cells (e.g., $\mathrm{Tr} 1$ or Th3 cells) can be enticed to such reversal of phenoytpe in vivo. In considering whether inflammatory environments may differentially affect the phenotype of regulatory $\mathrm{T}$ cells (or dendritic cells), we query whether the regulatory $\mathrm{T}$ cells that are naturally associated with a specific compartment (e.g., Th3 cells in the gut) might be more resistant to reversal of phenotype by challenges they would routinely encounter in that compartment than other regulatory T cells (e.g., Treg, Tr1). Finally, we raise the issue of whether in some specific settings, it might be advisable to activate multiple types of regulatory $\mathrm{T}$ cell responses, such that the tolerance so induced might be less susceptible by reversal by subsequent coincidental inflammatory events.

\section{CLINICAL APPLICATION OF TOLEROGENIC DENDRITIC CELLS}

The first tolerogenic dendritic cell study in humans was undertaken by Ralph Steinman's lab. They demonstrated that s.c. administration of antigen-loaded immature dendritic cells $\left(2 \times 10^{6}\right.$ cells/subject) was well tolerated by the study subjects and also that the treatments could suppress antigen-specific $\mathrm{CD}^{+} \mathrm{T}$ cell responses (128) for $\leq 6$ months (127). More recently a clinical trial was undertaken with 10 subjects with type 1 diabetes, each of whom was given $1 \times 10^{7}$ autologous dendritic cells intradermally four times at 2 week intervals; the treatment cells had been transduced with anti-sense oligonucleotides to silence co-stimulatory molecules (i.e., CD40, CD80, and CD86), although efficacy data on that silencing was not reported (292). The authors had developed their silencing protocols in a mouse model of type 1 diabetes and shown that the dendritic cell treatments had had statistically significant, though quite modest, disease-sparing effects (293). As with the earlier study by Steinman $(127,128)$, there were no adverse events related to the dendritic cell treatments in this latter study, but there were few if any immunologically discernible tolerance outcomes attributable to the dendritic cell treatments (292).

There have been a large number of in vitro studies performed as proof of principle that tolerogenic dendritic cells can efficiently reduce Teff cell responses in humans. As noted above, it was shown that semi-mature IL-10-differentiated dendritic cells (i.e., DC10) generated from atopic asthmatic donors can suppress the responses of autologous $\mathrm{T}$ cell to specific allergen. Moreover, the DC10 induce the outgrowth of immunosuppressive $\mathrm{CD}^{+}{ }^{+} \mathrm{CD} 25^{+}$Foxp $^{+}{ }^{+} \mathrm{LAG}^{+}{ }^{+} \mathrm{CTLA}_{4}{ }^{+}$Treg from the peripheral blood Teff cell pool (30). Others have reported that DC-VitD/Dex from individuals with rheumatoid arthritis (294) or DC-VitD3 from subjects with relapsing-remitting multiple sclerosis (295) are both able to suppress autologous $\mathrm{CD} 4^{+}$Teff cell responses to specific antigen-presenting mature dendritic cells.

In conclusion, it is clear that multiple mediators can induce a tolerogenic phenotype in dendritic cells, and that these substantially influence the conversations that occur between the dendritic cell and naive or Teff cells. These tolerogenic dendritic cells employ both secreted mediators (e.g., IL-10, retinoic acid) and inhibitory receptors to drive regulatory $\mathrm{T}$ cell induction, but can also provide additional signals (e.g., integrins) to direct these nascent Treg to the appropriate anatomic compartment (Figure 1). A major challenge we will face in the application of such tolerogenic dendritic cells for immunotherapy will be to carefully match or optimize the type(s) of tolerogenic dendritic cells to be employed with the clinical targets and desired endpoints.

\section{AUTHOR CONTRIBUTIONS}

Wojciech Dawicki reviewed the literature for and wrote parts of the section on naturally occurring populations of dendritic cells, Yanna Ma contributed to the section on T cell biology, Laura Churchman wrote the introduction, Sara A. Gordon collated the literature on the different types of dendritic cells that have been reported, and John R. Gordon wrote the section on the different types of experimental dendritic cells that have been reported. All authors contributed to the planning and editorial phases of the review.

\section{ACKNOWLEDGMENTS}

This work was supported by grants from the Canadian Institutes of Health Research (MOP53167) and AllerGen National Centres of Excellence (CanFAST6).

\section{REFERENCES}

1. Steinman RM. Decisions about dendritic cells: past, present, and future. Annu Rev Immunol (2012) 30:1-22. doi:10.1146/annurev-immunol-100311-102839

2. Gowans JL. The role of lymphocytes in the destruction of homografts. Br Med Bull (1965) 21:106-10.

3. Steinman RM, Cohn ZA. Identification of a novel cell type in peripheral lymphoid organs of mice. I. Morphology, quantitation, tissue distribution. J Exp Med (1973) 137(5):1142-62. doi:10.1084/jem.137.5.1142

4. Steinman RM, Cohn ZA. Identification of a novel cell type in peripheral lymphoid organs of mice. II. Functional properties in vitro. J Exp Med (1974) 139(2):380-97. doi:10.1084/jem.139.6.1431

5. Steinman RM, Kaplan G, Witmer MD, Cohn ZA. Identification of a novel cell type in peripheral lymphoid organs of mice. V. Purification of spleen dendritic cells, new surface markers, and maintenance in vitro. J Exp Med (1979) 149(1):1-16. doi:10.1084/jem.149.1.1

6. Steinman RM, Witmer MD. Lymphoid dendritic cells are potent stimulators of the primary mixed leukocyte reaction in mice. Proc Natl Acad Sci U S A (1978) 75(10):5132-6. doi:10.1073/pnas.75.10.5132

7. Steinman RM. The dendritic cell system and its role in immunogenicity. Annu Rev Immunol (1991) 9:271-96. doi:10.1146/annurev.iy.09.040191.001415 
8. Simon JC, Tigelaar RE, Bergstresser PR, Edelbaum D, Cruz PD Jr. Ultraviolet $\mathrm{B}$ radiation converts Langerhans cells from immunogenic to tolerogenic antigen-presenting cells. Induction of specific clonal anergy in CD4+ T helper 1 cells. J Immunol (1991) 146:485-91.

9. Enk AH, Angeloni VL, Udey MC, Katz SI. Inhibition of Langerhans cell antigenpresenting function by IL-10. A role for IL-10 in induction of tolerance. J Immunol (1993) 151(5):2390-8.

10. Steptoe RJ, Thomson AW. Dendritic cells and tolerance induction. Clin Exp Immunol (1996) 105(3):397-402.

11. Bamboat ZM, Stableford JA, Plitas G, Burt BM, Nguyen HM, Welles AP, et al. Human liver dendritic cells promote $\mathrm{T}$ cell hyporesponsiveness. J Immunol (2009) 182(4):1901-11. doi:10.4049/jimmunol.0803404

12. Banchereau J, Briere F, Caux C, Davoust J, Lebecque S, Liu YJ, et al. Immunobiology of dendritic cells. Annu Rev Immunol (2000) 18:767-811. doi:10.1146/ annurev.immunol.18.1.767

13. Merad M, Sathe P, Helft J, Miller J, Mortha A. The dendritic cell lineage: ontogeny and function of dendritic cells and their subsets in the steady state and the inflamed setting. Annu Rev Immunol (2013) 31:563-604. doi:10.1146/ annurev-immunol-020711-074950

14. Caux C, Ait-Yahia S, Chemin K, de Bouteiller O, Dieu-Nosjean MC, Homey $B$, et al. Dendritic cell biology and regulation of dendritic cell trafficking by chemokines. Springer Semin Immunopathol (2000) 22(4):345-69. doi:10.1007/ s002810000053

15. de Heer HJ, Hammad H, Kool M, Lambrecht BN. Dendritic cell subsets and immune regulation in the lung. Semin Immunol (2005) 17(4):295-303. doi:10.1016/j.smim.2005.05.002

16. Groux H, Fournier N, Cottrez F. Role of dendritic cells in the generation of regulatory T cells. Semin Immunol (2004) 16(2):99-106. doi:10.1016/j.smim. 2003.12.004

17. Saeki H, Moore AM, Brown MJ, Hwang ST. Cutting edge: secondary lymphoidtissue chemokine (SLC) and CC chemokine receptor 7 (CCR7) participate in the emigration pathway of mature dendritic cells from the skin to regional lymph nodes. J Immunol (1999) 162(5):2472-5.

18. Romani N, Koide S, Crowley M, Witmer-Pack M, Livingstone AM, Fathman $\mathrm{CG}$, et al. Presentation of exogenous protein antigens by dendritic cells to $\mathrm{T}$ cell clones. Intact protein is presented best by immature, epidermal Langerhans cells. J Exp Med (1989) 169:1169-78. doi:10.1084/jem.169.3.1169

19. Hart DN. Dendritic cells: unique leukocyte populations which control the primary immune response. Blood (1997) 90(9):3245-87.

20. Heufler C, Koch F, Stanzl U, Topar G, Wysocka M, Trinchieri G, et al. Interleukin-12 is produced by dendritic cells and mediates T helper 1 development as well as interferon-gamma production by Thelper 1 cells. Eur J Immunol (1996) 26(3):659-68. doi:10.1002/eji.1830260323

21. Weiner HL, da Cunha AP, Quintana F, Wu H. Oral tolerance. Immunol Rev (2011) 241(1):241-59. doi:10.1111/j.1600-065X.2011.01017.x

22. Sigmundsdottir H, Pan J, Debes GF, Alt C, Habtezion A, Soler D, et al. DCs metabolize sunlight-induced vitamin D3 to "program" $\mathrm{T}$ cell attraction to the epidermal chemokine CCL27. Nat Immunol (2007) 8(3):285-93. doi:10.1038/nil433

23. Sun CM, Hall JA, Blank RB, Bouladoux N, Oukka M, Mora JR, et al. Small intestine lamina propria dendritic cells promote de novo generation of Foxp3 T reg cells via retinoic acid. J Exp Med (2007) 204(8):1775-85. doi:10.1084/jem.20070602

24. Akbari O, DeKruyff RH, Umetsu DT. Pulmonary dendritic cells producing IL10 mediate tolerance induced by respiratory exposure to antigen. Nat Immunol (2001) 2(8):725-31. doi:10.1038/90667

25. Ueno H, Klechevsky E, Schmitt N, Ni L, Flamar AL, Zurawski S, et al. Targeting human dendritic cell subsets for improved vaccines. Semin Immunol (2011) 23(1):21-7. doi:10.1016/j.smim.2011.01.004

26. Randolph GJ, Angeli V, Swartz MA. Dendritic-cell trafficking to lymph nodes through lymphatic vessels. Nat Rev Immunol (2005) 5(8):617-28. doi:10.1038/ nri1670

27. Liu K, Waskow C, Liu X, Yao K, Hoh J, Nussenzweig M. Origin of dendritic cells in peripheral lymphoid organs of mice. Nat Immunol (2007) 8(6):578-83. doi:10.1038/ni1462

28. Randolph GJ, Ochando J, Partida-Sanchez S. Migration of dendritic cell subsets and their precursors. Annu Rev Immunol (2008) 26:293-316. doi:10.1146/ annurev.immunol.26.021607.090254
29. Sallusto F, Lanzavecchia A. Efficient presentation of soluble antigen by cultured human dendritic cells is maintained by granulocyte/macrophage colonystimulating factor plus interleukin 4 and downregulated by tumor necrosis factor alpha. J Exp Med (1994) 179(4):1109-18. doi:10.1084/jem.179.4.1109

30. Li X, Yang A, Huang H, Zhang X, Town J, Davis B, et al. Induction of type $2 \mathrm{~T}$ helper cell allergen tolerance by IL-10-differentiated regulatory dendritic cells. Am J Respir Cell Mol Biol (2010) 42(2):190-9. doi:10.1165/rcmb.2009-0023OC

31. Cheong C, Matos I, Choi JH, Dandamudi DB, Shrestha E, Longhi MP, et al. Microbial stimulation fully differentiates monocytes to DC-SIGN/CD209(+) dendritic cells for immune T cell areas. Cell (2010) 143(3):416-29. doi:10.1016/ j.cell.2010.09.039

32. Nizzoli G, Krietsch J, Weick A, Steinfelder S, Facciotti F, Gruarin P, et al. Human CD1c+ dendritic cells secrete high levels of IL-12 and potently prime cytotoxic T-cell responses. Blood (2013) 122(6):932-42. doi:10.1182/blood-201304-495424

33. Gregori S, Tomasoni D, Pacciani V, Scirpoli M, Battaglia M, Magnani CF, et al. Differentiation of type 1 T regulatory cells $(\operatorname{Tr} 1)$ by tolerogenic $\mathrm{DC}-10$ requires the IL-10-dependent ILT4/HLA-G pathway. Blood (2010) 116(6):935-44. doi:10.1182/blood-2009-07-234872

34. Scott CL, Aumeunier AM, Mowat AM. Intestinal CD103+ dendritic cells: master regulators of tolerance? Trends Immunol (2011) 32(9):412-9. doi:10.1016/ j.it.2011.06.003

35. Medzhitov R. Recognition of microorganisms and activation of the immune response. Nature (2007) 449(7164):819-26. doi:10.1038/nature06246

36. Steinman RM, Banchereau J. Taking dendritic cells into medicine. Nature (2007) 449(7161):419-26. doi:10.1038/nature06175

37. Farache J, Koren I, Milo I, Gurevich I, Kim KW, Zigmond E, et al. Luminal bacteria recruit CD103+ dendritic cells into the intestinal epithelium to sample bacterial antigens for presentation. Immunity (2013) 38(3):581-95. doi:10.1016/j.immuni.2013.01.009

38. Schulz O, Jaensson E, Persson EK, Liu X, Worbs T, Agace WW, et al. Intestinal CD103+, but not CX3CR1+, antigen sampling cells migrate in lymph and serve classical dendritic cell functions. J Exp Med (2009) 206(13):3101-14. doi:10.1084/jem.20091925

39. Mucida D, Pino-Lagos K, Kim G, Nowak E, Benson MJ, Kronenberg M, et al. Retinoic acid can directly promote TGF-beta-mediated Foxp3(+) Treg cell conversion of naive T cells. Immunity (2009) 30(4):471-2; author reply 2-3. doi:10.1016/j.immuni.2009.03.008

40. Sharma MD, Baban B, Chandler P, Hou DY, Singh N, Yagita H, et al. Plasmacytoid dendritic cells from mouse tumor-draining lymph nodes directly activate mature Tregs via indoleamine 2,3-dioxygenase. J Clin Invest (2007) 117(9):2570-82. doi:10.1172/JCI31911

41. Semmrich M, Plantinga M, Svensson-Frej M, Uronen-Hansson H, Gustafsson T, Mowat AM, et al. Directed antigen targeting in vivo identifies a role for CD103+ dendritic cells in both tolerogenic and immunogenic T-cell responses. Mucosal Immunol (2012) 5(2):150-60. doi:10.1038/mi.2011.61

42. Laffont S, Siddiqui KR, Powrie F. Intestinal inflammation abrogates the tolerogenic properties of MLN CD103+ dendritic cells. Eur J Immunol (2010) 40(7):1877-83. doi:10.1002/eji.200939957

43. del Rio ML, Bernhardt G, Rodriguez-Barbosa JI, Forster R. Development and functional specialization of CD103+ dendritic cells. Immunol Rev (2010) 234(1):268-81. doi:10.1111/j.0105-2896.2009.00874.x

44. Johansson-Lindbom B, Svensson M, Pabst O, Palmqvist C, Marquez G, Forster $\mathrm{R}$, et al. Functional specialization of gut CD103+ dendritic cells in the regulation of tissue-selective T cell homing. J Exp Med (2005) 202(8):1063-73. doi:10.1084/jem.20051100

45. Hall JA, Grainger JR, Spencer SP, Belkaid Y. The role of retinoic acid in tolerance and immunity. Immunity (2011) 35(1):13-22. doi:10.1016/j.immuni. 2011.07.002

46. den Hartog G, van Altena C, Savelkoul HF, van Neerven RJ. The mucosal factors retinoic acid and TGF-betal induce phenotypically and functionally distinct dendritic cell types. Int Arch Allergy Immunol (2013) 162(3):225-36. doi:10.1159/000353243

47. Wurbel MA, McIntire MG, Dwyer P, Fiebiger E. CCL25/CCR9 interactions regulate large intestinal inflammation in a murine model of acute colitis. PLoS One (2011) 6(1):e16442. doi:10.1371/journal.pone.0016442

48. Bowman EP, Kuklin NA, Youngman KR, Lazarus NH, Kunkel EJ, Pan J, et al. The intestinal chemokine thymus-expressed chemokine (CCL25) attracts IgA 
antibody-secreting cells. J Exp Med (2002) 195(2):269-75. doi:10.1084/jem. 20010670

49. Mucida D, Park Y, Kim G, Turovskaya O, Scott I, Kronenberg M, et al. Reciprocal TH17 and regulatory $\mathrm{T}$ cell differentiation mediated by retinoic acid. Science (2007) 317(5835):256-60. doi:10.1126/science.1145697

50. Cong Y, Feng T, Fujihashi K, Schoeb TR, Elson CO. A dominant, coordinated T regulatory cell-IgA response to the intestinal microbiota. Proc Natl Acad Sci U S A (2009) 106(46):19256-61. doi:10.1073/pnas.0812681106

51. Uematsu S, Fujimoto K, Jang MH, Yang BG, Jung YJ, Nishiyama M, et al. Regulation of humoral and cellular gut immunity by lamina propria dendritic cells expressing Toll-like receptor 5. Nat Immunol (2008) 9(7):769-76. doi:10.1038/ ni. 1622

52. Cerutti A, Rescigno M. The biology of intestinal immunoglobulin A responses. Immunity (2008) 28(6):740-50. doi:10.1016/j.immuni.2008.05.001

53. von Garnier C, Filgueira L, Wikstrom M, Smith M, Thomas JA, Strickland DH, et al. Anatomical location determines the distribution and function of dendritic cells and other APCs in the respiratory tract. J Immunol (2005) 175(3):1609-18.

54. Holt PG, Schon-Hegrad MA, Oliver J, Holt BJ, McMenamin PG. A contiguous network of dendritic antigen-presenting cells within the respiratory epithelium. Int Arch Allergy Appl Immunol (1990) 91(2):155-9. doi:10.1159/ 000235107

55. Robays LJ, Maes T, Joos GF, Vermaelen KY. Between a cough and a wheeze: dendritic cells at the nexus of tobacco smoke-induced allergic airway sensitization. Mucosal Immunol (2009) 2(3):206-19. doi:10.1038/mi.2009.7

56. Veres TZ, Rochlitzer S, Shevchenko M, Fuchs B, Prenzler F, Nassenstein C, et al. Spatial interactions between dendritic cells and sensory nerves in allergic airway inflammation. Am J Respir Cell Mol Biol (2007) 37(5):553-61. doi:10.1165/rcmb.2007-0087OC

57. Holt PG, Schon-Hegrad MA. Localization of T cells, macrophages and dendritic cells in rat respiratory tract tissue: implications for immune function studies. Immunology (1987) 62(3):349-56.

58. Huh JC, Strickland DH, Jahnsen FL, Turner DJ, Thomas JA, Napoli S, et al. Bidirectional interactions between antigen-bearing respiratory tract dendritic cells (DCs) and T cells precede the late phase reaction in experimental asthma: DC activation occurs in the airway mucosa but not in the lung parenchyma. J Exp Med (2003) 198(1):19-30. doi:10.1084/jem.20021328

59. Plantinga M, Hammad H, Lambrecht BN. Origin and functional specializations of DC subsets in the lung. Eur J Immunol (2010) 40(8):2112-8. doi:10.1002/eji.201040562

60. Demedts IK, Brusselle GG, Vermaelen KY, Pauwels RA. Identification and characterization of human pulmonary dendritic cells. Am J Respir Cell Mol Biol (2005) 32(3):177-84. doi:10.1165/rcmb.2004-0279OC

61. Lambrecht BN, Hammad H. Lung dendritic cells in respiratory viral infection and asthma: from protection to immunopathology. Annu Rev Immunol (2012) 30:243-70. doi:10.1146/annurev-immunol-020711-075021

62. Van Pottelberge GR, Bracke KR, Demedts IK, De Rijck K, Reinartz SM, van Drunen CM, et al. Selective accumulation of langerhans-type dendritic cells in small airways of patients with COPD. Respir Res (2010) 11:35. doi:10.1186/1465-9921-11-35

63. Asselin-Paturel C, Brizard G, Pin JJ, Briere F, Trinchieri G. Mouse strain differences in plasmacytoid dendritic cell frequency and function revealed by a novel monoclonal antibody. J Immunol (2003) 171(12):6466-77.

64. de Heer HJ, Hammad H, Soullie T, Hijdra D, Vos N, Willart MA, et al. Essential role of lung plasmacytoid dendritic cells in preventing asthmatic reactions to harmless inhaled antigen. J Exp Med (2004) 200(1):89-98. doi:10.1084/jem. 20040035

65. Gehrie E, Van der Touw W, Bromberg JS, Ochando JC. Plasmacytoid dendritic cells in tolerance. Methods Mol Biol (2011) 677:127-47. doi:10.1007/978-160761-869-0_9

66. Wang $\mathrm{H}$, Peters $\mathrm{N}$, Schwarze J. Plasmacytoid dendritic cells limit viral replication, pulmonary inflammation, and airway hyperresponsiveness in respiratory syncytial virus infection. J Immunol (2006) 177(9):6263-70.

67. Ho AW, Prabhu N, Betts RJ, Ge MQ, Dai X, Hutchinson PE, et al. Lung CD103+ dendritic cells efficiently transport influenza virus to the lymph node and load viral antigen onto MHC class I for presentation to CD8 T cells. J Immunol (2011) 187(11):6011-21. doi:10.4049/jimmunol.1100987

68. del Rio ML, Rodriguez-Barbosa JI, Kremmer E, Forster R. CD103- and CD103+ bronchial lymph node dendritic cells are specialized in presenting and cross-presenting innocuous antigen to $\mathrm{CD} 4+$ and $\mathrm{CD} 8+\mathrm{T}$ cells. J Immunol (2007) 178(11):6861-6.

69. Plantinga M, Guilliams M, Vanheerswynghels M, Deswarte K, Branco-Madeira F, Toussaint $\mathrm{W}$, et al. Conventional and monocyte-derived $\mathrm{CD} 11 \mathrm{~b}(+)$ dendritic cells initiate and maintain T helper 2 cell-mediated immunity to house dust mite allergen. Immunity (2013) 38(2):322-35. doi:10.1016/j.immuni. 2012.10.016

70. van Rijt LS, Jung S, Kleinjan A, Vos N, Willart M, Duez C, et al. In vivo depletion of lung $\mathrm{CD} 11 \mathrm{c}+$ dendritic cells during allergen challenge abrogates the characteristic features of asthma. J Exp Med (2005) 201(6):981-91. doi:10.1084/jem.20042311

71. Jonuleit H, Schmitt E, Steinbrink K, Enk AH. Dendritic cells as a tool to induce anergic and regulatory T cells. Trends Immunol (2001) 22(7):394-400. doi:10.1016/S1471-4906(01)01952-4

72. Fallarino F, Bianchi R, Orabona C, Vacca C, Belladonna ML, Fioretti MC, et al. CTLA-4-Ig activates forkhead transcription factors and protects dendritic cells from oxidative stress in nonobese diabetic mice. J Exp Med (2004) 200(8):1051-62. doi:10.1084/jem.20040942

73. Khare A, Krishnamoorthy N, Oriss TB, Fei M, Ray P, Ray A. Cutting edge: inhaled antigen upregulates retinaldehyde dehydrogenase in lung $\mathrm{CD} 103+$ but not plasmacytoid dendritic cells to induce Foxp3 de novo in CD4+ T cells and promote airway tolerance. J Immunol (2013) 191(1):25-9. doi:10.4049/ jimmunol.1300193

74. Soroosh P, Doherty TA, Duan W, Mehta AK, Choi H, Adams YF, et al. Lung-resident tissue macrophages generate Foxp3+ regulatory $\mathrm{T}$ cells and promote airway tolerance. J Exp Med (2013) 210(4):775-88. doi:10.1084/jem. 20121849

75. Coleman MM, Ruane D, Moran B, Dunne PJ, Keane J, Mills KH. Alveolar macrophages contribute to respiratory tolerance by inducing FoxP3 expression in naive T cells. Am J Respir Cell Mol Biol (2013) 48(6):773-80. doi:10.1165/rcmb.2012-0263OC

76. Holt PG, Oliver J, Bilyk N, McMenamin C, McMenamin PG, Kraal G, et al. Downregulation of the antigen presenting cell function(s) of pulmonary dendritic cells in vivo by resident alveolar macrophages. J Exp Med (1993) 177(2):397-407. doi:10.1084/jem.177.2.397

77. Chorro L, Geissmann F. Development and homeostasis of "resident" myeloid cells: the case of the Langerhans cell. Trends Immunol (2010) 31(12):438-45. doi:10.1016/j.it.2010.09.003

78. Merad M, Ginhoux F, Collin M. Origin, homeostasis and function of Langerhans cells and other langerin-expressing dendritic cells. Nat Rev Immunol (2008) 8(12):935-47. doi:10.1038/nri2455

79. Valladeau J, Saeland S. Cutaneous dendritic cells. Semin Immunol (2005) 17(4):273-83. doi:10.1016/j.smim.2005.05.009

80. Igyarto BZ, Haley K, Ortner D, Bobr A, Gerami-Nejad M, Edelson BT, et al. Skin-resident murine dendritic cell subsets promote distinct and opposing antigen-specific T helper cell responses. Immunity (2011) 35(2):260-72. doi:10.1016/j.immuni.2011.06.005

81. Henri S, Poulin LF, Tamoutounour S, Ardouin L, Guilliams M, de Bovis B. CD207+ CD103+ dermal dendritic cells cross-present keratinocyte-derived antigens irrespective of the presence of Langerhans cells. J Exp Med (2010) 207:189-206. doi:10.1084/jem.20091964

82. Teunissen MB, Haniffa M, Collin MP. Insight into the immunobiology of human skin and functional specialization of skin dendritic cell subsets to innovate intradermal vaccination design. Curr Top Microbiol Immunol (2012) 351:25-76. doi:10.1007/82_2011_169

83. Idoyaga J, Fiorese C, Zbytnuik L, Lubkin A, Miller J, Malissen B, et al. Specialized role of migratory dendritic cells in peripheral tolerance induction. J Clin Invest (2013) 123:844-54. doi:10.1172/JCI65260

84. Shklovskaya E, O'Sullivan BJ, Ng LG, Roediger B, Thomas R, Weninger W, et al. Langerhans cells are precommitted to immune tolerance induction. Proc Natl Acad Sci U S A (2011) 108(44):18049-54. doi:10.1073/pnas.1110076108

85. van der Aar AM, Picavet DI, Muller FJ, de Boer L, van Capel TM, Zaat SA, et al. Langerhans cells favor skin flora tolerance through limited presentation of bacterial antigens and induction of regulatory $\mathrm{T}$ cells. J Invest Dermatol (2013) 133(5):1240-9. doi:10.1038/jid.2012.500

86. O'Sullivan BJ, Thomas R. CD40 ligation conditions dendritic cell antigenpresenting function through sustained activation of NF-kappaB. J Immunol (2002) 168(11):5491-8. 
87. Kaplan DH, Jenison MC, Saeland S, Shlomchik WD, Shlomchik MJ. Epidermal langerhans cell-deficient mice develop enhanced contact hypersensitivity. Immunity (2005) 23:611-20. doi:10.1016/j.immuni.2005.10.008

88. Bennett CL, van Rijn E, Jung S, Inaba K, Steinman RM, Kapsenberg ML, et al. Inducible ablation of mouse Langerhans cells diminishes but fails to abrogate contact hypersensitivity. J Cell Biol (2005) 169(4):569-76. doi:10.1083/ jcb. 200501071

89. Gomez de Aguero M, Vocanson M, Hacini-Rachinel F, Taillardet M, Sparwasser T, Kissenpfennig A, et al. Langerhans cells protect from allergic contact dermatitis in mice by tolerizing CD8(+) T cells and activating Foxp3(+) regulatory T cells. J Clin Invest (2012) 122(5):1700-11. doi:10.1172/JCI59725

90. Chu CC, Ali N, Karagiannis P, Di Meglio P, Skowera A, Napolitano L, et al. Resident CD141 (BDCA3)+ dendritic cells in human skin produce IL-10 and induce regulatory T cells that suppress skin inflammation. J Exp Med (2012) 209(5):935-45. doi:10.1084/jem.20112583

91. Azukizawa H, Dohler A, Kanazawa N, Nayak A, Lipp M, Malissen B, et al. Steady state migratory RelB+ langerin+ dermal dendritic cells mediate peripheral induction of antigen-specific CD4+ CD25+ Foxp3+ regulatory T cells. Eur J Immunol (2011) 41(5):1420-34. doi:10.1002/eji.201040930

92. Castellaneta A, Mazariegos GV, Nayyar N, Zeevi A, Thomson AW. HLA-G level on monocytoid dendritic cells correlates with regulatory T-cell Foxp3 expression in liver transplant tolerance. Transplantation (2011) 91(10):1132-40. doi:10.1097/TP.0b013e31821414c9

93. Bamboat ZM, Ocuin LM, Balachandran VP, Obaid H, Plitas G, DeMatteo RP. Conventional DCs reduce liver ischemia/reperfusion injury in mice via IL-10 secretion. J Clin Invest (2010) 120(2):559-69. doi:10.1172/JCI40008

94. Chen Y, Jiang G, Yang HR, Gu X, Wang L, Hsieh CC, et al. Distinct response of liver myeloid dendritic cells to endotoxin is mediated by IL-27. J Hepatol (2009) 51(3):510-9. doi:10.1016/j.jhep.2009.04.026

95. Jinushi M, Takehara T, Tatsumi T, Yamaguchi S, Sakamori R, Hiramatsu N, et al. Natural killer cell and hepatic cell interaction via NKG2A leads to dendritic cell-mediated induction of CD4 CD25 T cells with PD-1-dependent regulatory activities. Immunology (2007) 120(1):73-82. doi:10.1111/j.1365-2567. 2006.02479.x

96. Xia S, Guo Z, Xu X, Yi H, Wang Q, Cao X. Hepatic microenvironment programs hematopoietic progenitor differentiation into regulatory dendritic cells, maintaining liver tolerance. Blood (2008) 112(8):3175-85. doi:10.1182/blood2008-05-159921

97. Dubois B, Joubert G, Gomez de Aguero M, Gouanvic M, Goubier A, Kaiserlian D. Sequential role of plasmacytoid dendritic cells and regulatory $\mathrm{T}$ cells in oral tolerance. Gastroenterology (2009) 137(3):1019-28. doi:10.1053/j.gastro.2009. 03.055

98. Goubier A, Dubois B, Gheit H, Joubert G, Villard-Truc F, Asselin-Paturel C, et al. Plasmacytoid dendritic cells mediate oral tolerance. Immunity (2008) 29(3):464-75. doi:10.1016/j.immuni.2008.06.017

99. Friedman SL. Hepatic stellate cells: protean, multifunctional, and enigmatic cells of the liver. Physiol Rev (2008) 88(1):125-72. doi:10.1152/physrev.00013. 2007

100. Dunham RM, Thapa M, Velazquez VM, Elrod EJ, Denning TL, Pulendran B, et al. Hepatic stellate cells preferentially induce Foxp3+ regulatory T cells by production of retinoic acid. J Immunol (2013) 190(5):2009-16. doi:10.4049/jimmunol.1201937

101. Ichikawa S, Mucida D, Tyznik AJ, Kronenberg M, Cheroutre H. Hepatic stellate cells function as regulatory bystanders. J Immunol (2011) 186(10):5549-55. doi:10.4049/jimmunol.1003917

102. You Q, Cheng L, Kedl RM, Ju C. Mechanism of T cell tolerance induction by murine hepatic Kupffer cells. Hepatology (2008) 48(3):978-90. doi:10.1002/ hep. 22395

103. Wilson NS, El-Sukkari D, Belz GT, Smith CM, Steptoe RJ, Heath WR, et al. Most lymphoid organ dendritic cell types are phenotypically and functionally immature. Blood (2003) 102(6):2187-94. doi:10.1182/blood-2003-02-0513

104. Fukaya T, Takagi H, Taya H, Sato K. DCs in immune tolerance in steady-state conditions. Methods Mol Biol (2011) 677:113-26. doi:10.1007/978-1-60761869-0_8

105. Broggi A, Zanoni I, Granucci F. Migratory conventional dendritic cells in the induction of peripheral T-cell tolerance. J Leukoc Biol (2013) 94(5):903-11. doi:10.1189/jlb.0413222
106. Doan T, McNally A, Thomas R, Steptoe RJ. Steady-state dendritic cells continuously inactivate $\mathrm{T}$ cells that escape thymic negative selection. Immunol Cell Biol (2009) 87(8):615-22. doi:10.1038/icb.2009.46

107. Gordon JR, Li F, Nayyar A, Xiang J, Zhang X. CD8 alpha+, but not CD8 alpha-, dendritic cells tolerize Th2 responses via contact-dependent and -independent mechanisms, and reverse airway hyperresponsiveness, Th2, and eosinophil responses in a mouse model of asthma. J Immunol (2005) 175(3):1516-22.

108. Zhang X, Huang H, Yuan J, Sun D, Hou WS, Gordon J, et al. CD4-8- dendritic cells prime CD4+ T regulatory 1 cells to suppress antitumor immunity. J Immunol (2005) 175:2931-7.

109. Winkel K, Kronin V, Krummel M, Shortman K. The nature of the signals regulating CD8 $\mathrm{T}$ cell proliferative responses to CD8a+ or CD8a- dendritic cells. Eur J Immunol (1997) 27:3350-9. doi:10.1002/eji.1830271234

110. Kronin V, Fitzmaurice CJ, Caminschi I, Shortman K, Jackson DC, Brown LE. Differential effect of CD8(+) and CD8(-) dendritic cells in the stimulation of secondary CD4(+) T cells. Int Immunol (2001) 13(4):465-73. doi:10.1093/intimm/13.4.465

111. Suss G, Shortman K. A subclass of dendritic cells kills CD4 T cells via Fas/Fasligand-induced apoptosis. J Exp Med (1996) 183(4):1789-96. doi:10.1084/jem. 183.4.1789

112. Holt PG, Upham JW. The role of dendritic cells in asthma. Curr Opin Allergy Clin Immunol (2004) 4(1):39-44. doi:10.1097/00130832-200402000-00009

113. Stern JN, Keskin DB, Kato Z, Waldner H, Schallenberg S, Anderson A, et al. Promoting tolerance to proteolipid protein-induced experimental autoimmune encephalomyelitis through targeting dendritic cells. Proc Natl Acad Sci U S A (2010) 107(40):17280-5. doi:10.1073/pnas.1010263107

114. Ring S, Maas M, Nettelbeck DM, Enk AH, Mahnke K. Targeting of autoantigens to DEC205+ Dendritic cells in vivo suppresses experimental allergic encephalomyelitis in mice. J Immunol (2013) 191(6):2938-47. doi:10.4049/ jimmunol.1202592

115. Petzold C, Schallenberg S, Stern JN, Kretschmer K. Targeted antigen delivery to DEC-205(+) dendritic cells for tolerogenic vaccination. Rev Diabet Stud (2012) 9(4):305-18. doi:10.1900/RDS.2012.9.305

116. Kushwah R, Wu J, Oliver JR, Jiang G, Zhang J, Siminovitch KA, et al. Uptake of apoptotic DC converts immature DC into tolerogenic DC that induce differentiation of Foxp3+ Treg. Eur J Immunol (2010) 40(4):1022-35. doi:10.1002/eji.200939782

117. Gleisner MA, Rosemblatt M, Fierro JA, Bono MR. Delivery of alloantigens via apoptotic cells generates dendritic cells with an immature tolerogenic phenotype. Transplant Proc (2011) 43(6):2325-33. doi:10.1016/j.transproceed.2011. 06.007

118. Kushwah R, Oliver JR, Zhang J, Siminovitch KA, Hu J. Apoptotic dendritic cells induce tolerance in mice through suppression of dendritic cell maturation and induction of antigen-specific regulatory T cells. J Immunol (2009) 183(11):7104-18. doi:10.4049/jimmunol.0900824

119. Jonuleit H, Schmitt E, Schuler G, Knop J, Enk AH. Induction of interleukin 10-producing, nonproliferating CD4(+) T cells with regulatory properties by repetitive stimulation with allogeneic immature human dendritic cells. J Exp Med (2000) 192(9):1213-22. doi:10.1084/jem.192.9.1213

120. Mahnke K, Schmitt E, Bonifaz L, Enk AH, Jonuleit H. Immature, but not inactive: the tolerogenic function of immature dendritic cells. Immunol Cell Biol (2002) 80(5):477-83. doi:10.1046/j.1440-1711.2002.01115.x

121. Bell E. Immature human dendritic cells induce regulatory $\mathrm{T}$ cells in vitro. Trends Immunol (2001) 22(1):11. doi:10.1016/S1471-4906(00)01833-0

122. Hubo M, Trinschek B, Kryczanowsky F, Tuettenberg A, Steinbrink K, Jonuleit H. Costimulatory molecules on immunogenic versus tolerogenic human dendritic cells. Front Immunol (2013) 4:82. doi:10.3389/fimmu.2013.00082

123. Chen C, Qu QX, Huang JA, Zhu YB, Ge Y, Wang Q, et al. Expression of programmed-death receptor ligands 1 and 2 may contribute to the poor stimulatory potential of murine immature dendritic cells. Immunobiology (2007) 212(3):159-65. doi:10.1016/j.imbio.2007.01.004

124. Chen Z, Gordon JR, Zhang X, Xiang J. Analysis of the gene expression profiles of immature versus mature bone marrow-derived dendritic cells using DNA arrays. Biochem Biophys Res Commun (2002) 290(1):66-72. doi:10.1006/bbrc. 2001.6147

125. Zhou F, Ciric B, Zhang GX, Rostami A. Immune tolerance induced by intravenous transfer of immature dendritic cells via up-regulating numbers of 
suppressive IL-10(+) IFN-gamma(+)-producing CD4(+) T cells. Immunol Res (2013) 56(1):1-8. doi:10.1007/s12026-012-8382-7

126. Charbonnier LM, van Duivenvoorde LM, Apparailly F, Cantos C, Han WG, Noel $\mathrm{D}$, et al. Immature dendritic cells suppress collagen-induced arthritis by in vivo expansion of CD49b + regulatory T cells. J Immunol (2006) 177(6):3806-13.

127. Dhodapkar MV, Steinman RM. Antigen-bearing immature dendritic cells induce peptide-specific CD8(+) regulatory T cells in vivo in humans. Blood (2002) 100(1):174-7. doi:10.1182/blood.V100.1.174

128. Dhodapkar MV, Steinman RM, Krasovsky J, Munz C, Bhardwaj N. Antigenspecific inhibition of effector T cell function in humans after injection of immature dendritic cells. JExp Med (2001) 193(2):233-8. doi:10.1084/jem.193.2.233

129. Gad M, Kristensen NN, Kury E, Claesson MH. Characterization of T-regulatory cells, induced by immature dendritic cells, which inhibit enteroantigen-reactive colitis-inducing T-cell responses in vitro and in vivo. Immunology (2004) 113(4):499-508. doi:10.1111/j.1365-2567.2004.01977.x

130. Jin Y, Fuller L, Ciancio G, Burke GW III, Tzakis AG, Ricordi C, et al. Antigen presentation and immune regulatory capacity of immature and mature-enriched antigen presenting (dendritic) cells derived from human bone marrow. Hum Immunol (2004) 65(2):93-103. doi:10.1016/j.humimm.2003.11.002

131. Popov I, Li M, Zheng X, San H, Zhang X, Ichim TE, et al. Preventing autoimmune arthritis using antigen-specific immature dendritic cells: a novel tolerogenic vaccine. Arthritis Res Ther (2006) 8(5):R141. doi:10.1186/ar2031

132. Roncarolo MG, Levings MK, Traversari C. Differentiation of T regulatory cells by immature dendritic cells. J Exp Med (2001) 193(2):F5-9. doi:10.1084/jem. 193.2.F5

133. Voigtlander C, Rossner S, Cierpka E, Theiner G, Wiethe C, Menges M, et al. Dendritic cells matured with TNF can be further activated in vitro and after subcutaneous injection in vivo which converts their tolerogenicity into immunogenicity. J Immunother (2006) 29(4):407-15. doi:10.1097/01.cji.0000210081. 60178.b4

134. Lim DS, Kang MS, Jeong JA, Bae YS. Semi-mature DC are immunogenic and not tolerogenic when inoculated at a high dose in collagen-induced arthritis mice. Eur J Immunol (2009) 39(5):1334-43. doi:10.1002/eji.200838987

135. Enk AH, Jonuleit H, Saloga J, Knop J. Dendritic cells as mediators of tumorinduced tolerance in metastatic melanoma. Int J Cancer (1997) 73(3):309-16. doi:10.1002/(SICI)1097-0215(19971104)73:3<309::AID-IJC1>3.3.CO;2-B

136. Steinbrink K, Wolfl M, Jonuleit H, Knop J, Enk AH. Induction of tolerance by IL-10-treated dendritic cells. J Immunol (1997) 159(10):4772-80.

137. Lu M, Dawicki W, Zhang X, Huang H, Nayyar A, Gordon JR. Therapeutic induction of tolerance by IL-10-differentiated dendritic cells in a mouse model of house dust mite-asthma. Allergy (2011) 66(5):612-20. doi:10.1111/j.13989995.2010.02526.x

138. Nayyar A, Dawicki W, Huang H, Lu M, Zhang X, Gordon JR. Induction of prolonged asthma tolerance by IL-10-differentiated dendritic cells: differential impact on airway hyperresponsiveness and the Th2 immunoinflammatory response. J Immunol (2012) 189(1):72-9. doi:10.4049/jimmunol.1103286

139. Nayyar A, Gordon J. Tolerogenic bone marrow-derived dendritic cells modulate Th2 responses of pulmonary lymphocytes from mice with severe allergic lung disease. FASEB J (2004) 18:A1128.

140. Koya T, Matsuda H, Takeda K, Matsubara S, Miyahara N, Balhorn A, et al. IL-10-treated dendritic cells decrease airway hyperresponsiveness and airway inflammation in mice. J Allergy Clin Immunol (2007) 119(5):1241-50. doi:10.1016/j.jaci.2007.01.039

141. Bellinghausen I, Brand U, Steinbrink K, Enk AH, Knop J, Saloga J. Inhibition of human allergic T-cell responses by IL-10-treated dendritic cells: differences from hydrocortisone-treated dendritic cells. J Allergy Clin Immunol (2001) 108(2):242-9. doi:10.1067/mai.2001.117177

142. Beissert S, Hosoi J, Grabbe S, Asahina A, Granstein RD. IL-10 inhibits tumor antigen presentation by epidermal antigen-presenting cells. J Immunol (1995) 154(3):1280-6.

143. Boks MA, Kager-Groenland JR, Haasjes MS, Zwaginga JJ, van Ham SM, ten Brinke A. IL-10-generated tolerogenic dendritic cells are optimal for functional regulatory $\mathrm{T}$ cell induction - a comparative study of human clinical-applicable DC. Clin Immunol (2012) 142(3):332-42. doi:10.1016/j.clim.2011.11.011

144. Chen L, Qiu M, He W, Huang A, Liu J. Functional study of immature dendritic cells co-transfected with IL-10 and TGF-beta 1 genes in vitro. Mol Biol Rep (2012) 39(6):6633-9. doi:10.1007/s11033-012-1468-4
145. Figueroa-Vega N, Galindo-Rodriguez G, Bajana S, Portales-Perez D, AbudMendoza C, Sanchez-Torres C, et al. Phenotypic analysis of IL-10-treated, monocyte-derived dendritic cells in patients with systemic lupus erythematosus. Scand J Immunol (2006) 64(6):668-76. doi:10.1111/j.1365-3083.2006. 01849.x

146. Henry E, Desmet CJ, Garze V, Fievez L, Bedoret D, Heirman C, et al. Dendritic cells genetically engineered to express IL-10 induce long-lasting antigenspecific tolerance in experimental asthma. J Immunol (2008) 181(10):7230-42.

147. Li WM, Liu W, Gao C, Zhou BG, Yang SS, Wang Z, et al. Antigen-specific tolerance induced by IL-10 gene modified immature dendritic cells in experimental autoimmune myocarditis in rats. Chin Med J (Engl) (2006) 119(19):1646-52.

148. McBride JM, Jung T, de Vries JE, Aversa G. IL-10 alters DC function via modulation of cell surface molecules resulting in impaired T-cell responses. Cell Immunol (2002) 215(2):162-72. doi:10.1016/S0008-8749(02)00007-2

149. Yang S, Li W, Liu W, Gao C, Zhou B, Li S, et al. IL-10 gene modified dendritic cells induced antigen-specific tolerance in experimental autoimmune myocarditis. Clin Immunol (2006) 121(1):63-73. doi:10.1016/j.clim.2006.06. 009

150. Sato K, Yamashita N, Baba M, Matsuyama T. Modified myeloid dendritic cells act as regulatory dendritic cells to induce anergic and regulatory T cells. Blood (2003) 101(9):3581-9. doi:10.1182/blood-2002-09-2712

151. Menges M, Rossner S, Voigtlander C, Schindler H, Kukutsch NA, Bogdan C, et al. Repetitive injections of dendritic cells matured with tumor necrosis factor alpha induce antigen-specific protection of mice from autoimmunity. J Exp Med (2002) 195(1):15-21. doi:10.1084/jem.20011341

152. Visser L, Jan de Heer H, Boven LA, van Riel D, van Meurs M, Melief MJ, et al. Proinflammatory bacterial peptidoglycan as a cofactor for the development of central nervous system autoimmune disease. J Immunol (2005) 174(2):808-16.

153. Rutella S, Bonanno G, Procoli A, Mariotti A, de Ritis DG, Curti A, et al. Hepatocyte growth factor favors monocyte differentiation into regulatory interleukin (IL)-10++IL-12low/neg accessory cells with dendritic-cell features. Blood (2006) 108(1):218-27. doi:10.1182/blood-2005-08-3141

154. Brandt K, Bulfone-Paus S, Foster DC, Ruckert R. Interleukin-21 inhibits dendritic cell activation and maturation. Blood (2003) 102(12):4090-8. doi:10. 1182/blood-2003-03-0669

155. Watanabe N, Wang YH, Lee HK, Ito T, Cao W, Liu YJ. Hassall's corpuscles instruct dendritic cells to induce CD4+CD25+ regulatory T cells in human thymus. Nature (2005) 436(7054):1181-5. doi:10.1038/nature03886

156. Rutella S, Danese S, Leone G. Tolerogenic dendritic cells: cytokine modulation comes of age. Blood (2006) 108(5):1435-40. doi:10.1182/blood-2006-03006403

157. Zhang-Hoover J, Finn P, Stein-Streilein J. Modulation of ovalbumin-induced airway inflammation and hyperreactivity by tolerogenic APC. J Immunol (2005) 175(11):7117-24.

158. Torres-Aguilar H, Aguilar-Ruiz SR, Gonzalez-Perez G, Munguia R, Bajana S, Meraz-Rios MA, et al. Tolerogenic dendritic cells generated with different immunosuppressive cytokines induce antigen-specific anergy and regulatory properties in memory CD4+ T cells. J Immunol (2010) 184(4):1765-75. doi:10.4049/jimmunol.0902133

159. Piemonti L, Monti P, Allavena P, Sironi M, Soldini L, Leone BE, et al. Glucocorticoids affect human dendritic cell differentiation and maturation. J Immunol (1999) 162(11):6473-81.

160. Naranjo-Gomez M, Raich-Regue D, Onate C, Grau-Lopez L, Ramo-Tello C, Pujol-Borrell R, et al. Comparative study of clinical grade human tolerogenic dendritic cells. J Transl Med (2011) 9:89. doi:10.1186/1479-5876-9-89

161. Xia CQ, Peng R, Beato F, Clare-Salzler MJ. Dexamethasone induces IL-10producing monocyte-derived dendritic cells with durable immaturity. Scand J Immunol (2005) 62(1):45-54. doi:10.1111/j.1365-3083.2005.01640.x

162. Zimmer A, Luce S, Gaignier F, Nony E, Naveau M, Biola-Vidamment A, et al. Identification of a new phenotype of tolerogenic human dendritic cells induced by fungal proteases from Aspergillus oryzae. J Immunol (2011) 186(7):3966-76. doi:10.4049/jimmunol.1003184

163. Penna G, Adorini L. 1 Alpha,25-dihydroxyvitamin D3 inhibits differentiation, maturation, activation, and survival of dendritic cells leading to impaired alloreactive T cell activation. J Immunol (2000) 164(5):2405-11.

164. Chamorro S, Garcia-Vallejo JJ, Unger WW, Fernandes RJ, Bruijns SC, Laban S, et al. TLR triggering on tolerogenic dendritic cells results in TLR2 
up-regulation and a reduced proinflammatory immune program. J Immunol (2009) 183(5):2984-94. doi:10.4049/jimmunol.0801155

165. Ferreira GB, Kleijwegt FS, Waelkens E, Lage K, Nikolic T, Hansen DA, et al. Differential protein pathways in 1,25-dihydroxyvitamin $\mathrm{d}(3)$ and dexamethasone modulated tolerogenic human dendritic cells. J Proteome Res (2012) 11(2):941-71. doi:10.1021/pr200724e

166. Ferreira GB, van Etten E, Verstuyf A, Waer M, Overbergh L, Gysemans C, et al. 1,25-Dihydroxyvitamin D3 alters murine dendritic cell behaviour in vitro and in vivo. Diabetes Metab Res Rev (2011) 27(8):933-41. doi:10.1002/dmrr.1275

167. Kleijwegt FS, Laban S, Duinkerken G, Joosten AM, Zaldumbide A, Nikolic $\mathrm{T}$, et al. Critical role for TNF in the induction of human antigen-specific regulatory $\mathrm{T}$ cells by tolerogenic dendritic cells. J Immunol (2010) 185(3):1412-8. doi:10.4049/jimmunol.1000560

168. Palomares O, O'Mahony L, Akdis CA. The many routes of dendritic cells to ensure immune regulation. J Allergy Clin Immunol (2011) 127(6):1541-2. doi:10.1016/j.jaci.2011.04.002

169. Penna G, Amuchastegui S, Giarratana N, Daniel KC, Vulcano M, Sozzani S, et al. 1,25-Dihydroxyvitamin D3 selectively modulates tolerogenic properties in myeloid but not plasmacytoid dendritic cells. J Immunol (2007) 178(1):145-53.

170. Piemonti L, Monti P, Sironi M, Fraticelli P, Leone BE, Dal Cin E, et al. Vitamin D3 affects differentiation, maturation, and function of human monocytederived dendritic cells. J Immunol (2000) 164(9):4443-51.

171. Unger WW, Laban S, Kleijwegt FS, van der Slik AR, Roep BO. Induction of Treg by monocyte-derived DC modulated by vitamin D3 or dexamethasone: differential role for PD-L1. Eur J Immunol (2009) 39(11):3147-59. doi:10.1002/eji.200839103

172. van Halteren AG, Tysma OM, van Etten E, Mathieu C, Roep BO. 1Alpha,25dihydroxyvitamin D3 or analogue treated dendritic cells modulate human autoreactive $\mathrm{T}$ cells via the selective induction of apoptosis. J Autoimmun (2004) 23(3):233-9. doi:10.1016/j.jaut.2004.06.004

173. Battaglia M, Stabilini A, Roncarolo MG. Rapamycin selectively expands CD4+CD25+FoxP3+ regulatory T cells. Blood (2005) 105(12):4743-8. doi:10. 1182/blood-2004-10-3932

174. Macedo C, Turquist H, Metes D, Thomson AW. Immunoregulatory properties of rapamycin-conditioned monocyte-derived dendritic cells and their role in transplantation. Transplant Res (2012) 1(1):16. doi:10.1186/2047-1440-1- 16

175. Li X, Li JJ, Yang JY, Wang DS, Zhao W, Song WJ, et al. Tolerance induction by exosomes from immature dendritic cells and rapamycin in a mouse cardiac allograft model. PLoS One (2012) 7(8):e44045. doi:10.1371/journal.pone. 0044045

176. Gonzalez-Rey E, Chorny A, Fernandez-Martin A, Ganea D, Delgado M. Vasoactive intestinal peptide generates human tolerogenic dendritic cells that induce CD4 and CD8 regulatory T cells. Blood (2006) 107(9):3632-8. doi:10.1182/blood-2005-11-4497

177. Toscano MG, Delgado M, Kong W, Martin F, Skarica M, Ganea D. Dendritic cells transduced with lentiviral vectors expressing VIP differentiate into VIP-secreting tolerogenic-like DCs. Mol Ther (2010) 18(5):1035-45. doi:10.1038/mt.2009.293

178. Wu HY, Quintana FJ, da Cunha AP, Dake BT, Koeglsperger T, Starossom SC, et al. In vivo induction of $\operatorname{Tr} 1$ cells via mucosal dendritic cells and AHR signaling. PLoS One (2011) 6(8):e23618. doi:10.1371/journal.pone.0023618

179. Hackstein H, Morelli AE, Larregina AT, Ganster RW, Papworth GD, Logar AJ, et al. Aspirin inhibits in vitro maturation and in vivo immunostimulatory function of murine myeloid dendritic cells. J Immunol (2001) 166(12): 7053-62.

180. Li XL, Liu Y, Cao LL, Li H, Yue LT, Wang S, et al. Atorvastatin-modified dendritic cells in vitro ameliorate experimental autoimmune myasthenia gravis by up-regulated Treg cells and shifted Th1/Th17 to Th2 cytokines. Mol Cell Neurosci (2013) 56C:85-95. doi:10.1016/j.mcn.2013.03.005

181. Downing I, MacDonald SL, Atkinson AP, Turner ML, Kilpatrick DC. Drug modification of LPS-stimulated human monocyte-derived dendritic cells. Br J Biomed Sci (2012) 69(3):126-33.

182. Olivar R, Luque A, Naranjo-Gomez M, Quer J, Garcia de Frutos P, Borras $\mathrm{FE}$, et al. The alpha7beta 0 isoform of the complement regulator $\mathrm{C} 4 \mathrm{~b}-$ binding protein induces a semimature, anti-inflammatory state in dendritic cells. J Immunol (2013) 190(6):2857-72. doi:10.4049/jimmunol.1200503

183. Wu SF, Liu TM, Lin YC, Sytwu HK, Juan HF, Chen ST, et al. Immunomodulatory effect of decoy receptor 3 on the differentiation and function of bone marrow-derived dendritic cells in nonobese diabetic mice: from regulatory mechanism to clinical implication. J Leukoc Biol (2004) 75(2):293-306. doi:10.1189/jlb.0303119

184. Cedeno-Laurent F, Opperman M, Barthel SR, Kuchroo VK, Dimitroff CJ. Galectin-1 triggers an immunoregulatory signature in Th cells functionally defined by IL-10 expression. J Immunol (2012) 188(7):3127-37. doi:10.4049/ jimmunol.1103433

185. Ilarregui JM, Croci DO, Bianco GA, Toscano MA, Salatino M, Vermeulen $\mathrm{ME}$, et al. Tolerogenic signals delivered by dendritic cells to $\mathrm{T}$ cells through a galectin-1-driven immunoregulatory circuit involving interleukin 27 and interleukin 10. Nat Immunol (2009) 10(9):981-91. doi:10.1038/ni.1772

186. Chen HW, Chen HY, Wang LT, Wang FH, Fang LW, Lai HY, et al. Mesenchymal stem cells tune the development of monocyte-derived dendritic cells toward a myeloid-derived suppressive phenotype through growth-regulated oncogene chemokines. J Immunol (2013) 190(10):5065-77. doi:10.4049/jimmunol. 1202775

187. Trinath J, Hegde P, Sharma M, Maddur MS, Rabin M, Vallat JM, et al. Intravenous immunoglobulin expands regulatory $\mathrm{T}$ cells via induction of cyclooxygenase-2-dependent prostaglandin E2 in human dendritic cells. Blood (2013) 122(8):1419-27. doi:10.1182/blood-2012-11-468264

188. Crow AR, Brinc D, Lazarus AH. New insight into the mechanism of action of IVIg: the role of dendritic cells. J Thromb Haemost (2009) 7(Suppl 1):245-8. doi:10.1111/j.1538-7836.2009.03420.x

189. Matsumoto T, Hasegawa H, Onishi S, Ishizaki J, Suemori K, Yasukawa M. Protein kinase $\mathrm{C}$ inhibitor generates stable human tolerogenic dendritic cells. J Immunol (2013) 191(5):2247-57. doi:10.4049/jimmunol.1203053

190. Chang J, Thangamani S, Kim MH, Ulrich B, Morris SM Jr, Kim CH. Retinoic acid promotes the development of Arg1-expressing dendritic cells for the regulation of T-cell differentiation. Eur J Immunol (2013) 43(4):967-78. doi:10.1002/eji.201242772

191. Cassani B, Villablanca EJ, De Calisto J, Wang S, Mora JR. Vitamin A and immune regulation: role of retinoic acid in gut-associated dendritic cell education, immune protection and tolerance. Mol Aspects Med (2012) 33(1):63-76. doi:10.1016/j.mam.2011.11.001

192. Coombes JL, Siddiqui KR, Arancibia-Carcamo CV, Hall J, Sun CM, Belkaid Y, et al. A functionally specialized population of mucosal CD103+ DCs induces Foxp3+ regulatory T cells via a TGF-beta and retinoic acid-dependent mechanism. J Exp Med (2007) 204(8):1757-64. doi:10.1084/jem.20070590

193. Saurer L, McCullough KC, Summerfield A. In vitro induction of mucosatype dendritic cells by all-trans retinoic acid. J Immunol (2007) 179(6): 3504-14.

194. Zhang M, Liu F, Jia H, Zhang Q, Yin L, Liu W, et al. Inhibition of microRNA let-7i depresses maturation and functional state of dendritic cells in response to lipopolysaccharide stimulation via targeting suppressor of cytokine signaling 1. J Immunol (2011) 187:1674-83. doi:10.4049/jimmunol.1001937

195. Hilkens CM, Isaacs JD. Tolerogenic dendritic cell therapy for rheumatoid arthritis: where are we now? Clin Exp Immunol (2013) 172(2):148-57. doi: $10.1111 /$ cei. 12038

196. Boks MA, Zwaginga JJ, van Ham SM, ten Brinke A. An optimized CFSE-based $\mathrm{T}$-cell suppression assay to evaluate the suppressive capacity of regulatory $\mathrm{T}$ cells induced by human tolerogenic dendritic cells. Scand J Immunol (2010) 72(2):158-68. doi:10.1111/j.1365-3083.2010.02414.x

197. Cohen N, Mouly E, Hamdi H, Maillot MC, Pallardy M, Godot V, et al. GILZ expression in human dendritic cells redirects their maturation and prevents antigen-specific T lymphocyte response. Blood (2006) 107(5):2037-44. doi:10.1182/blood-2005-07-2760

198. Zimmer A, Bouley J, Le Mignon M, Pliquet E, Horiot S, Turfkruyer M, et al. A regulatory dendritic cell signature correlates with the clinical efficacy of allergen-specific sublingual immunotherapy. J Allergy Clin Immunol (2012) 129(4):1020-30. doi:10.1016/j.jaci.2012.02.014

199. Penna G, Roncari A, Amuchastegui S, Daniel KC, Berti E, Colonna M, et al. Expression of the inhibitory receptor ILT3 on dendritic cells is dispensable for induction of CD4+Foxp3+ regulatory T cells by 1,25-dihydroxyvitamin D3. Blood (2005) 106(10):3490-7. doi:10.1182/blood-2005-05-2044

200. van der Aar AM, Sibiryak DS, Bakdash G, van Capel TM, van der Kleij HP, Opstelten DJ, et al. Vitamin D3 targets epidermal and dermal dendritic cells for induction of distinct regulatory T cells. J Allergy Clin Immunol (2011) 127(6):1532-40.e7. doi:10.1016/j.jaci.2011.01.068 
201. Gong YB, Huang YF, Li Y, Han GC, Li YR, Wang DJ, et al. Experimental study of the mechanism of tolerance induction in dexamethasone-treated dendritic cells. Med Sci Monit (2011) 17(5):BR125-31. doi:10.12659/MSM.881758

202. Hontelez S, Karthaus N, Looman MW, Ansems M, Adema GJ. DC-SCRIPT regulates glucocorticoid receptor function and expression of its target GILZ in dendritic cells. J Immunol (2013) 190(7):3172-9. doi:10.4049/jimmunol. 1201776

203. Volchenkov R, Karlsen M, Jonsson R, Appel S. Type 1 regulatory T cells and regulatory B cells induced by tolerogenic dendritic cells. Scand J Immunol (2013) 77(4):246-54. doi:10.1111/sji.12039

204. Delgado M, Gonzalez-Rey E, Ganea D. Vasoactive intestinal peptide: the dendritic cell $\rightarrow$ regulatory T cell axis. Ann N Y Acad Sci (2006) 1070:233-8. doi:10.1196/annals.1317.020

205. Chi H. Regulation and function of mTOR signalling in T cell fate decisions. Nat Rev Immunol (2012) 12(5):325-38. doi:10.1038/nri3198

206. Coenen JJ, Koenen HJ, van Rijssen E, Hilbrands LB, Joosten I. Rapamycin, and not cyclosporin A, preserves the highly suppressive CD27+ subset of human CD4+CD25+ regulatory T cells. Blood (2006) 107(3):1018-23. doi:10.1182/ blood-2005-07-3032

207. Remes Lenicov F, Rodriguez Rodrigues C, Sabatte J, Cabrini M, Jancic C, Ostrowski M, et al. Semen promotes the differentiation of tolerogenic dendritic cells. J Immunol (2012) 189(10):4777-86. doi:10.4049/jimmunol.1202089

208. Teh BK, Yeo JG, Chern LM, Lu J. C1q regulation of dendritic cell development from monocytes with distinct cytokine production and $\mathrm{T}$ cell stimulation. $\mathrm{Mol}$ Immunol (2011) 48(9-10):1128-38. doi:10.1016/j.molimm.2011.02.006

209. De Smedt T, Van Mechelen M, De Becker G, Urbain J, Leo O, Moser M. Effect of interleukin-10 on dendritic cell maturation and function. Eur J Immunol (1997) 27:1229-35. doi:10.1002/eji.1830270526

210. Sato K, Yamashita N, Matsuyama T. Human peripheral blood monocytederived interleukin-10-induced semi-mature dendritic cells induce anergic CD4(+) and CD8(+) T cells via presentation of the internalized soluble antigen and cross-presentation of the phagocytosed necrotic cellular fragments. Cell Immunol (2002) 215(2):186-94. doi:10.1016/S0008-8749(02)00021-7

211. Steinbrink K, Graulich E, Kubsch S, Knop J, Enk AH. CD4(+) and CD8(+) anergic $\mathrm{T}$ cells induced by interleukin-10-treated human dendritic cells display antigen-specific suppressor activity. Blood (2002) 99(7):2468-76. doi:10.1182/ blood.V99.7.2468

212. Sato K, Nagayama H, Tadokoro K, Juji T, Takahashi TA. Extracellular signalregulated kinase, stress-activated protein kinase/c-Jun N-terminal kinase, and p38mapk are involved in IL-10-mediated selective repression of TNF-alphainduced activation and maturation of human peripheral blood monocytederived dendritic cells. J Immunol (1999) 162:3865-72.

213. Rethi B, Gogolak P, Szatmari I, Veres A, Erdos E, Nagy L, et al. SLAM/SLAM interactions inhibit CD40-induced production of inflammatory cytokines in monocyte-derived dendritic cells. Blood (2006) 107(7):2821-9. doi:10.1182/ blood-2005-06-2265

214. Huang H, Dawicki W, Lu M, Nayyar A, Zhang X, Gordon JR. Regulatory dendritic cell expression of MHCII and IL-10 are jointly requisite for induction of tolerance in a murine model of OVA-asthma. Allergy (2013) 68(9):1126-35. doi:10.1111/all.12203

215. Huang H, Dawicki W, Zhang X, Town J, Gordon JR. Tolerogenic dendritic cells induce CD4+CD25hiFoxp3+ regulatory T cell differentiation from CD4+CD25-/loFoxp3- effector T cells. J Immunol (2010) 185(9):5003-10. doi:10.4049/jimmunol.0903446

216. Nayyar A. Therapeutic Immunomodulation of Allergic Lung Disease Using Regulatory Dendritic Cells in a Mouse Model of Asthma. Ph.D. thesis, Saskatoon, SK: University of Saskatchewan (2009).

217. Huang H, Ma Y, Dawicki W, Zhang X, Gordon JR. Comparison of induced versus natural regulatory $\mathrm{T}$ cells of the same TCR specificity for induction of tolerance to an environmental antigen. J Immunol (2013) 191(3):1136-43. doi:10.4049/jimmunol.1201899

218. Levings MK, Gregori S, Tresoldi E, Cazzaniga S, Bonini C, Roncarolo MG. Differentiation of $\operatorname{Tr} 1$ cells by immature dendritic cells requires IL-10 but not CD25+CD4+ Tr cells. Blood (2005) 105(3):1162-9. doi:10.1182/blood-200403- 1211

219. Yang CY, Leung PS, Adamopoulos IE, Gershwin ME. The implication of vitamin D and autoimmunity: a comprehensive review. Clin Rev Allergy Immunol (2013) 45(2):217-26. doi:10.1007/s12016-013-8361-3
220. Pludowski P, Holick MF, Pilz S, Wagner CL, Hollis BW, Grant WB, et al. Vitamin $D$ effects on musculoskeletal health, immunity, autoimmunity, cardiovascular disease, cancer, fertility, pregnancy, dementia and mortality-A review of recent evidence. Autoimmun Rev (2013) 12(10):976-89. doi:10.1016/j.autrev.2013.02. 004

221. Griffin MD, Lutz WH, Phan VA, Bachman LA, McKean DJ, Kumar R. Potent inhibition of dendritic cell differentiation and maturation by vitamin D analogs. Biochem Biophys Res Commun (2000) 270(3):701-8. doi:10.1006/bbrc. 2000.2490

222. van Halteren AG, van Etten E, de Jong EC, Bouillon R, Roep BO, Mathieu C. Redirection of human autoreactive T-cells upon interaction with dendritic cells modulated by TX527, an analog of 1,25 dihydroxyvitamin $\mathrm{D}(3)$. Diabetes (2002) 51(7):2119-25. doi:10.2337/diabetes.51.7.2119

223. Adorini L. Tolerogenic dendritic cells induced by vitamin D receptor ligands enhance regulatory T cells inhibiting autoimmune diabetes. Ann N Y Acad Sci (2003) 987:258-61. doi:10.1111/j.1749-6632.2003.tb06057.x

224. Griffin MD, Lutz W, Phan VA, Bachman LA, McKean DJ, Kumar R. Dendritic cell modulation by lalpha, 25 dihydroxyvitamin D3 and its analogs: a vitamin D receptor-dependent pathway that promotes a persistent state of immaturity in vitro and in vivo. Proc Natl Acad Sci U S A (2001) 98(12):6800-5. doi:10.1073/pnas. 121172198

225. Sochorova K, Budinsky V, Rozkova D, Tobiasova Z, Dusilova-Sulkova S, Spisek $\mathrm{R}$, et al. Paricalcitol (19-nor-1,25-dihydroxyvitamin D2) and calcitriol (1,25dihydroxyvitamin D3) exert potent immunomodulatory effects on dendritic cells and inhibit induction of antigen-specific T cells. Clin Immunol (2009) 133(1):69-77. doi:10.1016/j.clim.2009.06.011

226. Kleijwegt FS, Laban S, Duinkerken G, Joosten AM, Koeleman BP, Nikolic T, et al. Transfer of regulatory properties from tolerogenic to proinflammatory dendritic cells via induced autoreactive regulatory T cells. J Immunol (2011) 187(12):6357-64. doi:10.4049/jimmunol.1101638

227. Coutinho AE, Chapman KE. The anti-inflammatory and immunosuppressive effects of glucocorticoids, recent developments and mechanistic insights. $\mathrm{Mol}$ Cell Endocrinol (2011) 335(1):2-13. doi:10.1016/j.mce.2010.04.005

228. Prado C, Gomez J, Lopez P, de Paz B, Gutierrez C, Suarez A. Dexamethasone upregulates FOXP3 expression without increasing regulatory activity. Immunobiology (2011) 216(3):386-92. doi:10.1016/j.imbio.2010.06.013

229. Woltman AM, de Fijter JW, Kamerling SW, Paul LC, Daha MR, van Kooten C. The effect of calcineurin inhibitors and corticosteroids on the differentiation of human dendritic cells. Eur J Immunol (2000) 30(7):1807-12. doi:10.1002/1521-4141(200007)30:7<1807::AID-IMMU1807>3.0.CO;2-N

230. Matasic R, Dietz AB, Vuk-Pavlovic S. Dexamethasone inhibits dendritic cell maturation by redirecting differentiation of a subset of cells. J Leukoc Biol (1999) 66(6):909-14.

231. Cao Y, Bender IK, Konstantinidis AK, Shin SC, Jewell CM, Cidlowski JA, et al. Glucocorticoid receptor translational isoforms underlie maturational stagespecific glucocorticoid sensitivities of dendritic cells in mice and humans. Blood (2013) 121(9):1553-62. doi:10.1182/blood-2012-05-432336

232. Rea D, van Kooten C, van Meijgaarden KE, Ottenhoff TH, Melief CJ, Offringa R. Glucocorticoids transform CD40-triggering of dendritic cells into an alternative activation pathway resulting in antigen-presenting cells that secrete IL-10. Blood (2000) 95:3162-7.

233. Bosma BM, Metselaar HJ, Nagtzaam NM, de Haan R, Mancham S, van der Laan LJ, et al. Dexamethasone transforms lipopolysaccharide-stimulated human blood myeloid dendritic cells into myeloid dendritic cells that prime interleukin-10 production in T cells. Immunology (2008) 125(1):91-100. doi:10.1111/j.1365-2567.2008.02824.x

234. Emmer PM, van der Vlag J, Adema GJ, Hilbrands LB. Dendritic cells activated by lipopolysaccharide after dexamethasone treatment induce donorspecific allograft hyporesponsiveness. Transplantation (2006) 81(10):1451-9. doi:10.1097/01.tp.0000208801.51222.bd

235. O’Flynn L, Treacy O, Ryan AE, Morcos M, Cregg M, Gerlach J, et al. Donor bone marrow-derived dendritic cells prolong corneal allograft survival and promote an intragraft immunoregulatory milieu. Mol Ther (2013) 21(11):2102-12. doi: $10.1038 / \mathrm{mt} .2013 .167$

236. de Kort H, Crul C, van der Wal AM, Schlagwein N, Stax AM, Bruijn JA, et al. Accelerated antibody-mediated graft loss of rodent pancreatic islets after pretreatment with dexamethasone-treated immature donor dendritic cells. Transplantation (2012) 94:903-10. doi:10.1097/TP.0b013e31826acd01 
237. Miller A, Lider O, Weiner HL. Antigen-driven bystander suppression after oral administration of antigens. J Exp Med (1991) 174(4):791-8. doi:10.1084/jem. 174.4.791

238. Derks RA, Jankowska-Gan E, Xu Q, Burlingham WJ. Dendritic cell type determines the mechanism of bystander suppression by adaptive $\mathrm{T}$ regulatory cells specific for the minor antigen HA-1. J Immunol (2007) 179(6):3443-51.

239. Kleijwegt FS, Jansen DT, Teeler J, Joosten AM, Laban S, Nikolic T, et al. Tolerogenic dendritic cells impede priming of naive CD8(+) T cells and deplete memory CD8(+) T cells. Eur J Immunol (2013) 43(1):85-92. doi:10.1002/eji. 201242879

240. Pedersen AE, Schmidt EG, Gad M, Poulsen SS, Claesson MH. Dexamethasone/ lalpha-25-dihydroxyvitamin D3-treated dendritic cells suppress colitis in the SCID T-cell transfer model. Immunology (2009) 127(3):354-64. doi:10.1111/ j.1365-2567.2008.02996.x

241. Said SI. The discovery of VIP: initially looked for in the lung, isolated from intestine, and identified as a neuropeptide. Peptides (2007) 28(9):1620-1. doi:10.1016/j.peptides.2007.06.007

242. Couvineau A, Laburthe M. VPAC receptors: structure, molecular pharmacology and interaction with accessory proteins. Br J Pharmacol (2012) 166(1):42-50. doi:10.1111/j.1476-5381.2011.01676.x

243. Pozo D, Anderson P, Gonzalez-Rey E. Induction of alloantigen-specific human T regulatory cells by vasoactive intestinal peptide. J Immunol (2009) 183(7):4346-59. doi:10.4049/jimmunol.0900400

244. Arranz A, Juarranz Y, Leceta J, Gomariz RP, Martinez C. VIP balances innate and adaptive immune responses induced by specific stimulation of TLR2 and TLR4. Peptides (2008) 29(6):948-56. doi:10.1016/j.peptides.2008.01.019

245. Chen G, Hao J, Xi Y, Wang W, Wang Z, Li N, et al. The therapeutic effect of vasoactive intestinal peptide on experimental arthritis is associated with CD4+CD25+ T regulatory cells. Scand J Immunol (2008) 68(6):572-8. doi:10.1111/j.1365-3083.2008.02178.x

246. Pozo D, Gonzalez-Rey E, Chorny A, Anderson P, Varela N, Delgado M. Tuning immune tolerance with vasoactive intestinal peptide: a new therapeutic approach for immune disorders. Peptides (2007) 28(9):1833-46. doi:10.1016/ j.peptides.2007.04.008

247. Chorny A, Gonzalez-Rey E, Fernandez-Martin A, Pozo D, Ganea D, Delgado $M$. Vasoactive intestinal peptide induces regulatory dendritic cells with therapeutic effects on autoimmune disorders. Proc Natl Acad Sci USA (2005) 102(38):13562-7. doi:10.1073/pnas.0504484102

248. Chorny A, Gonzalez-Rey E, Fernandez-Martin A, Ganea D, Delgado M. Vasoactive intestinal peptide induces regulatory dendritic cells that prevent acute graft-versus-host disease while maintaining the graft-versus-tumor response. Blood (2006) 107(9):3787-94. doi:10.1182/blood-2005-11-4495

249. Gonzalez-Rey E, Delgado M. Therapeutic treatment of experimental colitis with regulatory dendritic cells generated with vasoactive intestinal peptide. Gastroenterology (2006) 131(6):1799-811. doi:10.1053/j.gastro.2006.10.023

250. Delgado M. Generating tolerogenic dendritic cells with neuropeptides. Hum Immunol (2009) 70(5):300-7. doi:10.1016/j.humimm.2009.01.020

251. Delgado M, Chorny A, Ganea D, Gonzalez-Rey E. Vasoactive intestinal polypeptide induces regulatory dendritic cells that prevent acute graft versus host disease and leukemia relapse after bone marrow transplantation. Ann N Y Acad Sci (2006) 1070:226-32. doi:10.1196/annals.1317.019

252. Delgado M, Gonzalez-Rey E, Ganea D. The neuropeptide vasoactive intestinal peptide generates tolerogenic dendritic cells. J Immunol (2005) 175(11):7311-24.

253. Delgado M, Chorny A, Gonzalez-Rey E, Ganea D. Vasoactive intestinal peptide generates CD4+CD25+ regulatory T cells in vivo. J Leukoc Biol (2005) 78(6):1327-38. doi:10.1189/jlb.0605299

254. Fernandez-Martin A, Gonzalez-Rey E, Chorny A, Ganea D, Delgado M. Vasoactive intestinal peptide induces regulatory $\mathrm{T}$ cells during experimental autoimmune encephalomyelitis. Eur J Immunol (2006) 36(2):318-26. doi:10.1002/eji.200535430

255. Gonzalez-Rey E, Fernandez-Martin A, Chorny A, Delgado M. Vasoactive intestinal peptide induces $\mathrm{CD} 4+, \mathrm{CD} 25+\mathrm{T}$ regulatory cells with therapeutic effect in collagen-induced arthritis. Arthritis Rheum (2006) 54(3):864-76. doi:10.1002/art.21652

256. Waschek JA. VIP and PACAP: neuropeptide modulators of CNS inflammation, injury, and repair. Br J Pharmacol (2013) 169(3):512-23. doi:10.1111/ bph.12181
257. Hay N, Sonenberg N. Upstream and downstream of mTOR. Genes Dev (2004) 18(16):1926-45. doi:10.1101/gad.1212704

258. Battaglia M, Stabilini A, Migliavacca B, Horejs-Hoeck J, Kaupper T, Roncarolo MG. Rapamycin promotes expansion of functional CD4+CD25+FOXP3+ regulatory T cells of both healthy subjects and type 1 diabetic patients. J Immunol (2006) 177(12):8338-47.

259. Mahe E, Morelon E, Lechaton S, Sang KH, Mansouri R, Ducasse MF, et al. Cutaneous adverse events in renal transplant recipients receiving sirolimus-based therapy. Transplantation (2005) 79(4):476-82. doi:10.1097/01.TP.0000151630. 25127.3A

260. Haidinger M, Poglitsch M, Geyeregger R, Kasturi S, Zeyda M, Zlabinger GJ, et al. A versatile role of mammalian target of rapamycin in human dendritic cell function and differentiation. J Immunol (2010) 185(7):3919-31. doi:10.4049/jimmunol.1000296

261. Hackstein H, Taner T, Zahorchak AF, Morelli AE, Logar AJ, Gessner A, et al. Rapamycin inhibits IL-4 - induced dendritic cell maturation in vitro and dendritic cell mobilization and function in vivo. Blood (2003) 101(11):4457-63. doi:10.1182/blood-2002-11-3370

262. Turnquist HR, Raimondi G, Zahorchak AF, Fischer RT, Wang Z, Thomson AW. Rapamycin-conditioned dendritic cells are poor stimulators of allogeneic CD4+ T cells, but enrich for antigen-specific Foxp $3+\mathrm{T}$ regulatory cells and promote organ transplant tolerance. J Immunol (2007) 178(11): 7018-31.

263. Pothoven KL, Kheradmand T, Yang Q, Houlihan JL, Zhang H, Degutes M, et al. Rapamycin-conditioned donor dendritic cells differentiate CD4CD25Foxp3 T cells in vitro with TGF-betal for islet transplantation. Am J Transplant (2010) 10(8):1774-84. doi:10.1111/j.1600-6143.2010.03199.x

264. Fischer RT, Turnquist HR, Wang Z, Beer-Stolz D, Thomson AW. Rapamycinconditioned, alloantigen-pulsed myeloid dendritic cells present donor MHC class I/peptide via the semi-direct pathway and inhibit survival of antigenspecific CD8(+) T cells in vitro and in vivo. Transpl Immunol (2011) 25(1):20-6. doi:10.1016/j.trim.2011.05.001

265. Horibe EK, Sacks J, Unadkat J, Raimondi G, Wang Z, Ikeguchi R, et al. Rapamycin-conditioned, alloantigen-pulsed dendritic cells promote indefinite survival of vascularized skin allografts in association with $\mathrm{T}$ regulatory cell expansion. Transpl Immunol (2008) 18(4):307-18. doi:10.1016/j.trim.2007. 10.007

266. Taner T, Hackstein H, Wang Z, Morelli AE, Thomson AW. Rapamycintreated, alloantigen-pulsed host dendritic cells induce ag-specific T cell regulation and prolong graft survival. Am J Transplant (2005) 5(2):228-36. doi:10.1046/j.1600-6143.2004.00673.x

267. Huang YM, Yang JS, Xu LY, Link H, Xiao BG. Autoantigen-pulsed dendritic cells induce tolerance to experimental allergic encephalomyelitis (EAE) in Lewis rats. Clin Exp Immunol (2000) 122(3):437-44.

268. Pettersson A, Ciumas C, Chirsky V, Link H, Huang YM, Xiao BG. Dendritic cells exposed to estrogen in vitro exhibit therapeutic effects in ongoing experimental allergic encephalomyelitis. J Neuroimmunol (2004) 156(1-2):58-65. doi:10.1016/j.jneuroim.2004.07.004

269. Xiao BG, Huang YM, Yang JS, Xu LY, Link H. Bone marrow-derived dendritic cells from experimental allergic encephalomyelitis induce immune tolerance to EAE in Lewis rats. Clin Exp Immunol (2001) 125(2):300-9.

270. Yang JS, Xu LY, Huang YM, Van Der Meide PH, Link H, Xiao BG. Adherent dendritic cells expressing high levels of interleukin-10 and low levels of interleukin-12 induce antigen-specific tolerance to experimental autoimmune encephalomyelitis. Immunology (2000) 101(3):397-403. doi:10.1046/j.13652567.2000.00115.x

271. Zhang QH, Link H, Xiao BG. Efficacy of peripheral tolerance induced by dendritic cells is dependent on route of delivery. J Autoimmun (2004) 23(1):37-43. doi:10.1016/j.jaut.2004.03.010

272. Bellinghausen I, Sudowe S, Konig B, Reske-Kunz AB, Knop J, Saloga J. Interleukin-10-treated dendritic cells do not inhibit Th2 immune responses in ovalbumin/alum-sensitized mice. Int Arch Allergy Immunol (2006) 141(1):61-9. doi:10.1159/000094255

273. Zimmermann O, Homann JM, Bangert A, Muller AM, Hristov G, Goeser S, et al. Successful use of mRNA-nucleofection for overexpression of interleukin-10 in murine monocytes/macrophages for anti-inflammatory therapy in a murine model of autoimmune myocarditis. J Am Heart Assoc (2012) 1(6):e003293. doi:10.1161/JAHA.112.003293 
274. Besin G, Gaudreau S, Menard M, Guindi C, Dupuis G, Amrani A. Thymic stromal lymphopoietin and thymic stromal lymphopoietin-conditioned dendritic cells induce regulatory $\mathrm{T}$-cell differentiation and protection of NOD mice against diabetes. Diabetes (2008) 57(8):2107-17. doi:10.2337/db080171

275. Liang X, Ma L, Thai NL, Fung JJ, Qian S, Lu L. The role of liver-derived regulatory dendritic cells in prevention of type 1 diabetes. Immunology (2007) 120(2):251-60. doi:10.1111/j.1365-2567.2006.02496.x

276. Ezzelarab MB, Zahorchak AF, Lu L, Morelli AE, Chalasani G, Demetris AJ, et al. Regulatory dendritic cell infusion prolongs kidney allograft survival in nonhuman primates. Am J Transplant (2013) 13(8):1989-2005. doi:10.1111/ ajt.12310

277. Blanco P, Palucka AK, Pascual V, Banchereau J. Dendritic cells and cytokines in human inflammatory and autoimmune diseases. Cytokine Growth Factor Rev (2008) 19(1):41-52. doi:10.1016/j.cytogfr.2007.10.004

278. Hammer GE, Ma A. Molecular control of steady-state dendritic cell maturation and immune homeostasis. Annu Rev Immunol (2013) 31:743-91. doi:10.1146/annurev-immunol-020711-074929

279. Schreibelt G, Tel J, Sliepen KH, Benitez-Ribas D, Figdor CG, Adema GJ, et al. Toll-like receptor expression and function in human dendritic cell subsets: implications for dendritic cell-based anti-cancer immunotherapy. Cancer Immunol Immunother (2010) 59:1573-82. doi:10.1007/s00262-010-0833-1

280. Edwards AD, Diebold SS, Slack EM, Tomizawa H, Hemmi H, Kaisho T, et al. Toll-like receptor expression in murine DC subsets: lack of TLR7 expression by CD8 alpha+ DC correlates with unresponsiveness to imidazoquinolines. Eur J Immunol (2003) 33(4):827-33. doi:10.1002/eji.200323797

281. Delamarre L, Mellman I. Harnessing dendritic cells for immunotherapy. Semin Immunol (2011) 23(1):2-11. doi:10.1016/j.smim.2011.02.001

282. Arizmendi NG, Abel M, Mihara K, Davidson C, Polley D, Nadeem A, et al. Mucosal allergic sensitization to cockroach allergens is dependent on proteinase activity and proteinase-activated receptor-2 activation. J Immunol (2011) 186(5):3164-72. doi:10.4049/jimmunol.0903812

283. Ebeling C, Lam T, Gordon JR, Hollenberg MD, Vliagoftis H. Proteinaseactivated receptor- 2 promotes allergic sensitization to an inhaled antigen through a TNF-mediated pathway. J Immunol (2007) 179(5):2910-7.

284. Salazar F, Sewell HF, Shakib F, Ghaemmaghami AM. The role of lectins in allergic sensitization and allergic disease. J Allergy Clin Immunol (2013) 132(1):27-36. doi:10.1016/j.jaci.2013.02.001

285. Brosbol-Ravnborg A, Bundgaard B, Hollsberg P. Synergy between vitamin $\mathrm{D}(3)$ and toll-like receptor agonists regulates human dendritic cell response during maturation. Clin Dev Immunol (2013) 2013:807971. doi:10.1155/2013/ 807971

286. Cabezon R, Ricart E, Espana C, Panes J, Benitez-Ribas D. Gram-negative enterobacteria induce tolerogenic maturation in dexamethasone conditioned dendritic cells. PLoS One (2012) 7(12):e52456. doi:10.1371/journal.pone. 0052456

287. Luger R, Valookaran S, Knapp N, Vizzardelli C, Dohnal AM, Felzmann T. Toll-like receptor 4 engagement drives differentiation of human and murine dendritic cells from a pro- into an anti-inflammatory mode. PLoS One (2013) 8(2):e54879. doi:10.1371/journal.pone.0054879

288. Yates SF, Paterson AM, Nolan KF, Cobbold SP, Saunders NJ, Waldmann H, et al. Induction of regulatory $\mathrm{T}$ cells and dominant tolerance by dendritic cells incapable of full activation. J Immunol (2007) 179(2):967-76.

289. Nguyen KD, Vanichsarn C, Nadeau KC. Impaired IL-10-dependent induction of tolerogenic dendritic cells by CD4+CD25hiCD127lo/- natural regulatory T cells in human allergic asthma. Am J Respir Crit Care Med (2009) 180(9):823-33. doi:10.1164/rccm.200905-0761OC

290. Yurchenko E, Shio MT, Huang TC, Da Silva Martins M, Szyf M, Levings MK, et al. Inflammation-driven reprogramming of CD4+ Foxp3+ regulatory T cells into pathogenic Th1/Th17 T effectors is abrogated by mTOR inhibition in vivo. PLoS One (2012) 7(4):e35572. doi:10.1371/journal.pone.0035572

291. Xu L, Kitani A, Fuss I, Strober W. Cutting edge: regulatory T cells induce CD4+CD25-Foxp3- T cells or are self-induced to become Th17 cells in the absence of exogenous TGF-beta. J Immunol (2007) 178(11):6725-9.

292. Giannoukakis N, Phillips B, Finegold D, Harnaha J, Trucco M. Phase I (safety) study of autologous tolerogenic dendritic cells in type 1 diabetic patients. Diabetes Care (2011) 34(9):2026-32. doi:10.2337/dc11-0472

293. Machen J, Harnaha J, Lakomy R, Styche A, Trucco M, Giannoukakis N. Antisense oligonucleotides down-regulating costimulation confer diabetespreventive properties to nonobese diabetic mouse dendritic cells. J Immunol (2004) 173(7):4331-41.

294. Harry R, AE A, JD I, HIlkens C. Generation and characterisation of therapeutic tolerogenic dendritic cells for rheumatoid arthritis. Ann Rheum Dis (2010) 69(11):2042-50. doi:10.1136/ard.2009.126383

295. Raich-Regue D, Grau-López L, Naranjo-Gómez M, Ramo-Tello C, PujolBorrell R, Martínez-Cáceres E, et al. Stable antigen-specific T-cell hyporesponsiveness induced by tolerogenic dendritic cells from multiple sclerosis patients. Eur J Immunol (2012) 42(3):771-82. doi:10.1002/eji.201141835

Conflict of Interest Statement: The authors declare that the research was conducted in the absence of any commercial or financial relationships that could be construed as a potential conflict of interest.

Received: 21 October 2013; paper pending published: 24 December 2013; accepted: 07 January 2014; published online: 31 January 2014.

Citation: Gordon JR, Ma Y, Churchman L, Gordon SA and Dawicki W (2014) Regulatory dendritic cells for immunotherapy in immunologic diseases. Front. Immunol. 5:7. doi: 10.3389/fimmu.2014.00007

This article was submitted to Molecular Innate Immunity, a section of the journal Frontiers in Immunology.

Copyright (c) 2014 Gordon, Ma, Churchman, Gordon and Dawicki. This is an openaccess article distributed under the terms of the Creative Commons Attribution License (CC BY). The use, distribution or reproduction in other forums is permitted, provided the original author(s) or licensor are credited and that the original publication in this journal is cited, in accordance with accepted academic practice. No use, distribution or reproduction is permitted which does not comply with these terms. 